\title{
Effects and Distribution of Iron-Related Well- Screen Encrustation and Aquifer Biofouling in Suffolk County, Long Island, New York
}

By DONALD A. WALTER

U.S. GEOLOGICAL SURVEY

Water-Resources Investigations Report 96-4217

Prepared in cooperation with the

SUFFOLK COUNTY WATER AUTHORITY 


\section{U.S. DEPARTMENT OF THE INTERIOR BRUCE BABBITT, Secretary}

U.S. GEOLOGICAL SURVEY

Gordon P. Eaton, Director

For additional information write to:

U.S. Geological Survey 2045 Route 112, Bldg. 4 Coram, NY 11727
Copies of this report may be purchased from:

U.S. Geological Survey

Branch of Information Services Box 25286

Denver, CO 80225-0286 


\section{CONTENTS}

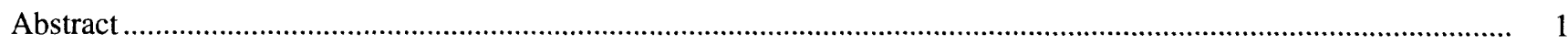

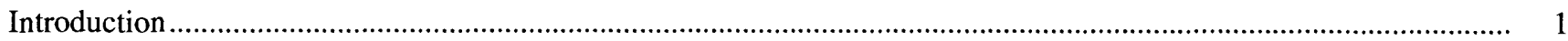

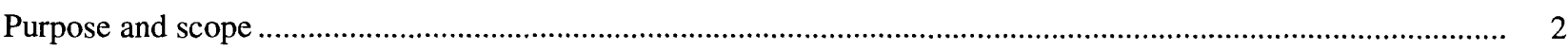

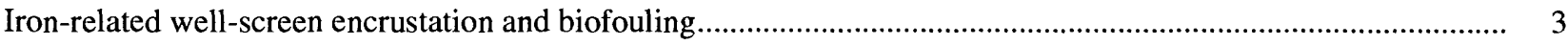

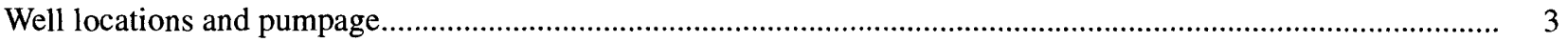

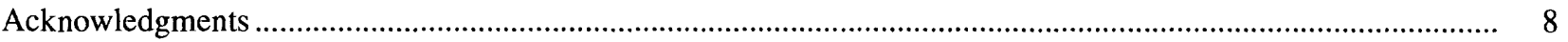

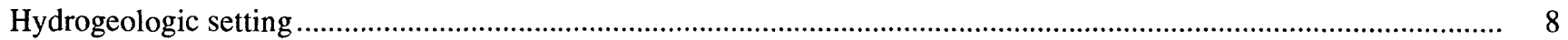

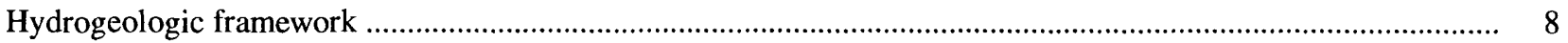

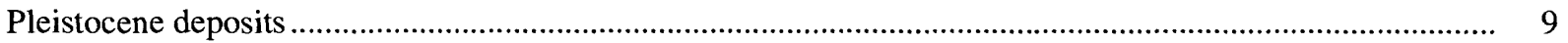

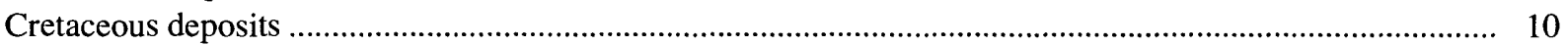

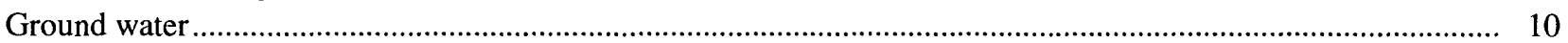

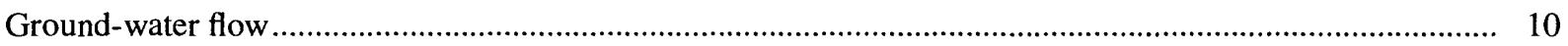

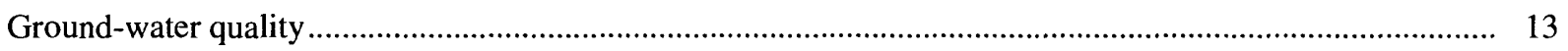

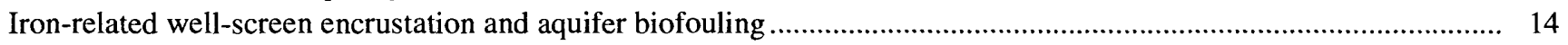

Effect of iron biofouling on specific capacity of wells ................................................................................. 15

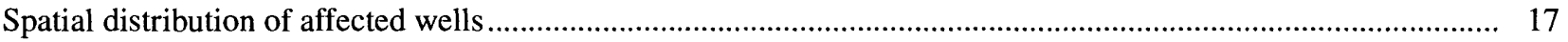

Relation of ground-water quality to specific-capacity decreases ..................................................................... 17

Spatial distribution of selected chemical constituents and properties.................................................................. 19

Iron

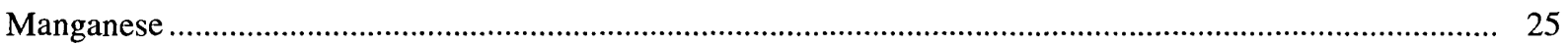

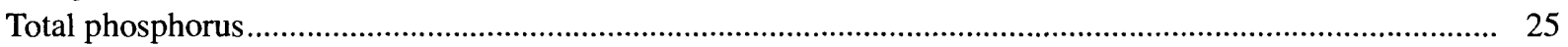

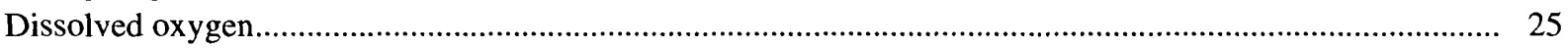

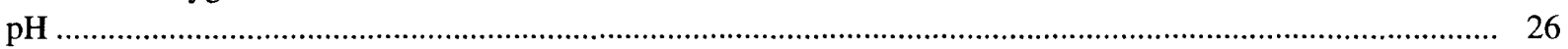

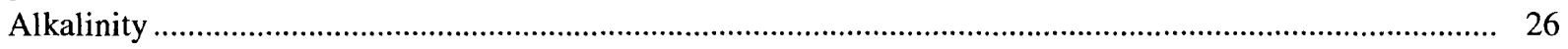

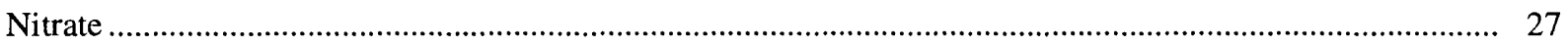

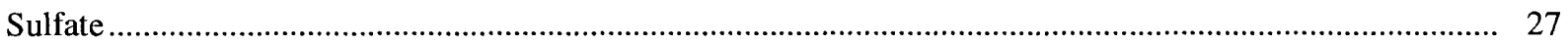

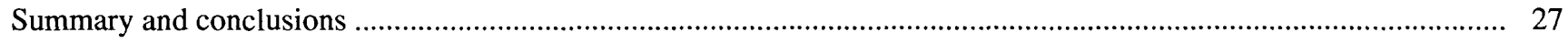

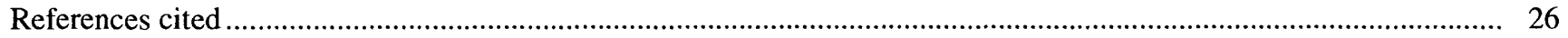

\section{FIGURES}

1. Map showing location of Suffolk County, N.Y.

2. Map of Suffolk County showing location of Suffolk County Water Authority (SCWA) pumping centers,

Long Island, N.Y., in (A) upper glacial aquifer, and (B) Magothy aquifer.....

3-5. Maps of Suffolk County showing areal distribution of ground-water withdrawals by:

3. Suffolk County Water Authority from the upper glacial aquifer, Long Island, N.Y., during (A) 1970-79, and (B) 1980-89.

4. Suffolk County Water Authority from the Magothy aquifer, Long Island, N.Y., during (A) 1970-79, and (B) $1980-89$....

5. All Suffolk County, Long Island, N.Y., water suppliers during 1985-89 from (A) upper glacial aquifer, and (B) Magothy aquifer

6-7. Generalized vertical sections showing:

6. Major hydrogeologic units near the Nassau-Suffolk County border, Long Island, N.Y.................................

7. Hydraulic heads and ground-water flow paths near the Nassau-Suffolk County border, Long Island, N.Y....... 11

8-9. Maps showing:

8. Ground-water levels in Suffolk County, N.Y., March 1991. A. Upper glacial (water-table) aquifer.

B. Magothy aquifer.

9. Location of ground-water recharge and discharge areas in Suffolk County, N.Y...................................... 


\section{FIGURES (continued)}

10. Histograms showing statistical distribution of specific-capacity data for the upper glacial and Magothy aquifers, Suffolk County, N.Y.: (A) and (D) Initial specific-capacity values. (B) and (E) Total specificcapacity decreases. (C) and (F) Mean annual specific-capacity decreases.....

11. Maps showing areal distribution of wells with iron-related specific-capacity declines in Suffolk County, N.Y., in (A) upper glacial aquifer, and (B) Magothy aquifer .....

12. Maps showing areal distribution of median values of selected constituents in wells screened in the Magothy aquifer, Suffolk County, N.Y.:

A. Total iron concentrations greater than 0.5 milligrams per liter.

B. Dissolved-iron concentrations greater than 0.25 milligrams per liter.

C. Total manganese concentrations greater than 0.01 milligrams per liter.

D. Total phosphate concentrations greater than 0.13 milligrams per liter.

E. Dissolved-oxygen concentrations greater than 2.0 milligrams per liter.

F. pH values less than 5.5 .

G. Total alkalinity concentration less than 10 milligrams per liter as $\mathrm{CaCO}_{3}$.

H. Nitrate concentrations less than 0.25 milligrams per liter.

\section{TABLES}

1. Pumpage by Suffolk County Water Authority and by other water suppliers, Suffolk County, N.Y., 1985-89

2. Generalized description of major hydrogeologic units underlying Suffolk County, N.Y.

3. Native water quality in Suffolk County, N.Y., as indicated by data from three previous studies

4. Ranges and median concentrations of selected constituents from NWIS data base for Magothy and upper glacial aquifers, Long Island, N.Y.

5. Specific-capacity data from 357 Suffolk County Water Authority wells, Suffolk County, N.Y., 1990-92

6. Statistical summary of water-quality data from unaffected and affected wells in Suffolk County, N.Y..

\section{CONVERSION FACTORS, ABBREVIATIONS AND VERTICAL DATUM}

$\begin{array}{lc}\text { Multiply } & \text { By } \\ & \text { Length } \\ \text { foot }(\mathrm{ft}) & 0.3048 \\ \text { mile }(\mathrm{mi}) & 1.609 \\ & \text { Area } \\ \text { square mile }\left(\mathrm{mi}^{2}\right) & 2.590 \\ & \text { Hydraulic conductivity } \\ \text { foot per day }(\mathrm{ft} / \mathrm{d}) & 0.3048 \\ & \text { Gradient } \\ \text { foot per mile }(\mathrm{ft} / \mathrm{mi}) & 0.1894 \\ & \text { Other abbreviations used in this report } \\ & \text { micrograms per liter }(\mu \mathrm{g} / \mathrm{L}) \\ & \text { milligrams per liter }(\mathrm{mg} / \mathrm{L})\end{array}$

Sea level: In this report, "sea level" refers to the National Geodetic Vertical Datum of 1929 (NGVD of 1929) - a geodetic datum derived from a general adjustment of the first-order level nets of the United States and Canada, formerly called Sea Level Datum of 1929. 


\title{
Effects And Distribution of Iron-Related Well-Screen Encrustation and Aquifer Biofouling in Suffolk County, Long Island, New York
}

\author{
By Donald A. Walter
}

\begin{abstract}
The process of iron-related well-screen encrustation and aquifer biofouling has led to significant decreases in the specific capacity of several wells in the Suffolk County Water Authority (SCWA) well network. Iron-related specific-capacity decreases from October 1990 through August 1992 prompted the SCWA to recondition 56 wells and to redrill an additional 3 wells from October 1990 through August 1992. The median decrease in specific capacity for SCWA wells screened in the Magothy aquifer was 3.4 percent per year, and the median decrease for wells screened in the upper glacial aquifer was 2.9 percent per year.
\end{abstract}

Most Magothy aquifer wells with annual specific-capacity decreases greater than or equal to 5.0 percent are in the southern and central parts of the county; most upper glacial aquifer wells with similar specific-capacity decreases are in the south-central part of the county. Most wells with large specific-capacity decreases are near ground-water-discharge zones along the coast and near streams.

Statistical comparisons of water-quality data from wells with annual specific-capacity decreases of at least 5.0 percent with data from wells having annual decreases of less than 5.0 percent indicated significant differences between the two groups in both aquifers. Water from Magothy aquifer wells with annual specific-capacity decreases of at least 5.0 percent had higher concentrations of total and dissolved iron, total and dissolved manganese, total phosphate, and dissolved sulfate than other Magothy aquifer wells, and lower concentrations of dissolved oxygen, nitrate, total alkalinity, and $\mathrm{pH}$ than water from other Magothy aquifer wells. Water from upper glacial aquifer wells with annual specific-capacity decreases of at least 5.0 percent had higher concentrations of total and dissolved manganese and dissolved sulfate, and lower $\mathrm{pH}$, than water from other upper glacial aquifer wells.

Elevated concentrations of total and dissolved iron, total manganese, total phosphate, and dissolved sulfate, and the low concentrations of dissolved oxygen and nitrate, were detected primarily in samples from wells completed in ground-water discharge zones in the Magothy aquifer. Most of the Magothy aquifer wells with low $\mathrm{pH}$ were in the southwestern part of the county, and most of those with low total alkalinity were in the western part.

\section{INTRODUCTION}

The aquifer system underlying Suffolk County, Long Island, N.Y., (fig. 1) has been designated a sole-source aquifer by the U.S. Environmental Protection Agency. The largest water supplier on Long Island, and the primary water supplier for Suffolk County, is the Suffolk County Water Authority (SCWA). Declines in the specific capacity ${ }^{1}$ of several wells in the SCWA well network since about 1970 have forced the SCWA to undertake a costly well-redevelopment and replacement program. The specific-capacity decreases are attributed to well-screen encrustation and biofouling by iron-related bacteria in the ground water, which are associated with elevated concentrations

\footnotetext{
${ }^{1}$ Specific capacity of a well is the rate of discharge of the well per unit of drawdown from non-pumping water level.
} 


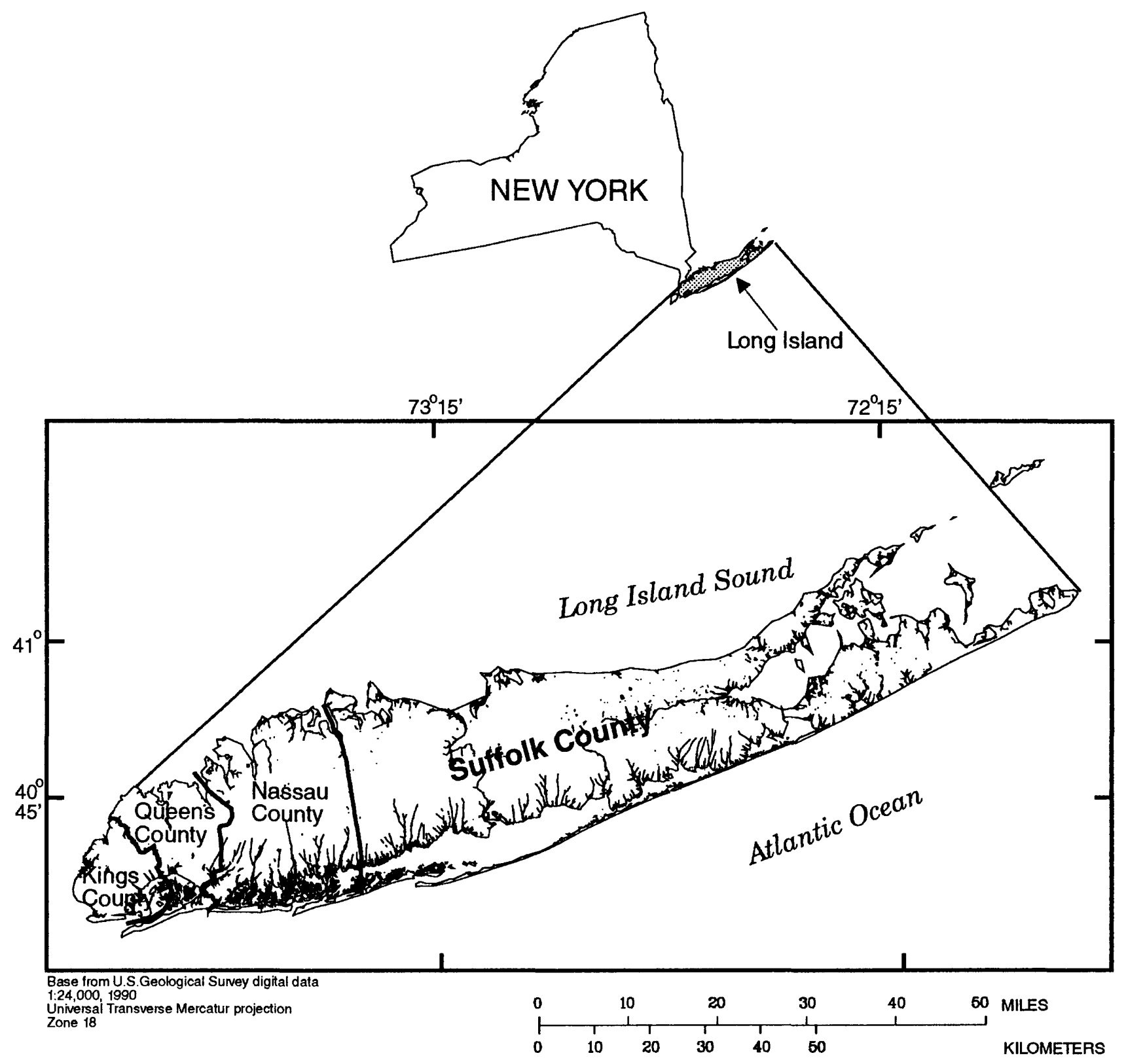

Figure 1. Location of Suffolk County, N.Y.

of iron. (In this report, the term "biofouling" refers to both the abiotic precipitation of ferric oxyhydroxides and the formation of biofilms by iron-oxidizing bacteria on well screens and in the pore spaces of the surrounding aquifer material.)

In 1990, the U.S. Geological Survey (USGS), in cooperation with the SCWA, began a 3-year study of iron-related well-screen encrustation in the two principal aquifers (upper glacial and Magothy) underlying Suffolk County. The investigation consisted of two components-a regional component that assessed the effects of iron-related production decreases in Suffolk County, and a site-specific component that assessed the geochemical and microbiological processes that contribute to well-screen encrustation and aquifer biofouling. This report discusses the results of the regional component of the study.

\section{Purpose and Scope}

This report (1) describes the effects of ironrelated well-screen encrustation on supply wells in the 
SCWA network, (2) depicts, by aquifer, the spatial distribution of supply wells that have had significant specific-capacity decreases, (3) compares the quality of water from wells that have had large specificcapacity declines with that from wells that have had only small declines, and (4) depicts the spatial distribution of water constituents that could be related to the specific-capacity declines.

\section{Iron-Related Well-Screen Encrustation and Biofouling}

Decreases in specific capacity are commonly associated with elevated concentrations of dissolved iron and are attributed to (1) the oxidation of ferrous iron and the subsequent precipitation of iron oxyhydroxides on well screens and in the pore spaces of the gravel pack and the surrounding formation, and (2) the growth of iron-bacteria biofilms on well screens and in pore spaces (Cullimore, 1986). The iron-bacteria biofilms consist primarily of extracellular organic material and ferric oxyhydroxides. The iron-oxidizing bacteria involved in the biofouling process require oxygen and include both heterotrophic and chemoautotrophic species. Chemoautotrophic iron-oxidizing bacteria are able to use $\mathrm{CO}_{2}$ as a carbon source and derive metabolic energy from the oxidation of ferrous iron. Heterotrophic iron-oxidizing bacteria require an organic carbon source and do not use ferrous iron oxidation as an energy source. Several taxonomic classes of iron bacteria have been identified as important biofouling agents (Cullimore, 1986). The species of ironoxidizing bacteria in a given biofouled well depends on the physiochemical conditions in the ground water, such as concentrations of dissolved iron and dissolved oxygen, $\mathrm{pH}$, and redox potential.

Iron-oxidizing bacteria grow in the vicinity of steep redox gradients and commonly are found in ground-water seeps and wetlands. A pumped well screened in a reducing environment can create an Eh gradient by mixing oxygenated water with water containing dissolved ferrous iron, and the resulting Eh gradient allows iron-oxidizing bacteria to grow within the zone of mixing around the well screen.

The decrease in specific capacity of wells through iron-related biofouling is of national and intemational concem (Cullimore, 1986). It can develop in a variety of hydrogeologic environments and is common in unconsolidated sediments such as those underlying Suffolk County (Driscoll, 1987).

\section{Well Locations and Pumpage}

The SCWA operated about 430 wells screened in the upper glacial aquifer and the underlying Magothy aquifer in 1992. The number of active wells fluctuates with periodic well shutdowns, abandonment, and the installation of new wells. Of the 430 wells, 216 are screened in the Magothy aquifer and 214 are screened in the upper glacial aquifer. In 1991, the SCWA withdrew 50.1 billion gallons of water for 1.2 million people. Locations of SCWA pumping centers that withdraw water from the Magothy and upper glacial aquifers are shown in figures $2 \mathrm{~A}$ and $2 \mathrm{~B}$, respectively; each pumping center has from 1 to 6 wells.

SCWA pumpage data for 1970-89 were collected from the New York State Department of Environmental Conservation (NYSDEC). The distribution and magnitude of SCWA withdrawals from the upper glacial aquifer during 1970-79 and 1980-89 (fig. 3A, $3 \mathrm{~B}$ ) indicates that the largest withdrawals were in the central and northwestern parts of the county. The distribution and magnitude of withdrawals from the Magothy aquifer during the same periods is shown in figures $4 \mathrm{~A}$ and $4 \mathrm{~B}$. The largest withdrawals from the Magothy aquifer are in the southwestern part of the county.

Pumpage data for 1985-89 from SCWA and other water suppliers in Suffolk County are summarized in table 1 . The distribution of ground-water withdrawals from the upper glacial and Magothy aquifers by all water suppliers in Suffolk County during 198589 are shown in figures $5 \mathrm{~A}$ and $5 \mathrm{~B}$, respectively.

Table 1. Pumpage by Suffolk County Water Authority and by other water suppliers, Suffolk County, N.Y., 1985-89

[Values are in billions of gallons. SCWA, Suffolk County Water Authority]

\begin{tabular}{lcrccc}
\hline & \multirow{2}{*}{$\begin{array}{c}\text { Total } \\
\text { Aquifer }\end{array}$} & pumpage & \multicolumn{2}{c}{ SCWA } & \multicolumn{2}{c}{ Others } \\
\cline { 3 - 6 } & Total & Percent & Total & Percent \\
\hline Magothy & 197,834 & 160,344 & 79.2 & 37,490 & 20.8 \\
Upper glacial & 100,120 & 79,878 & 79.8 & 20,242 & 20.2 \\
\hline
\end{tabular}



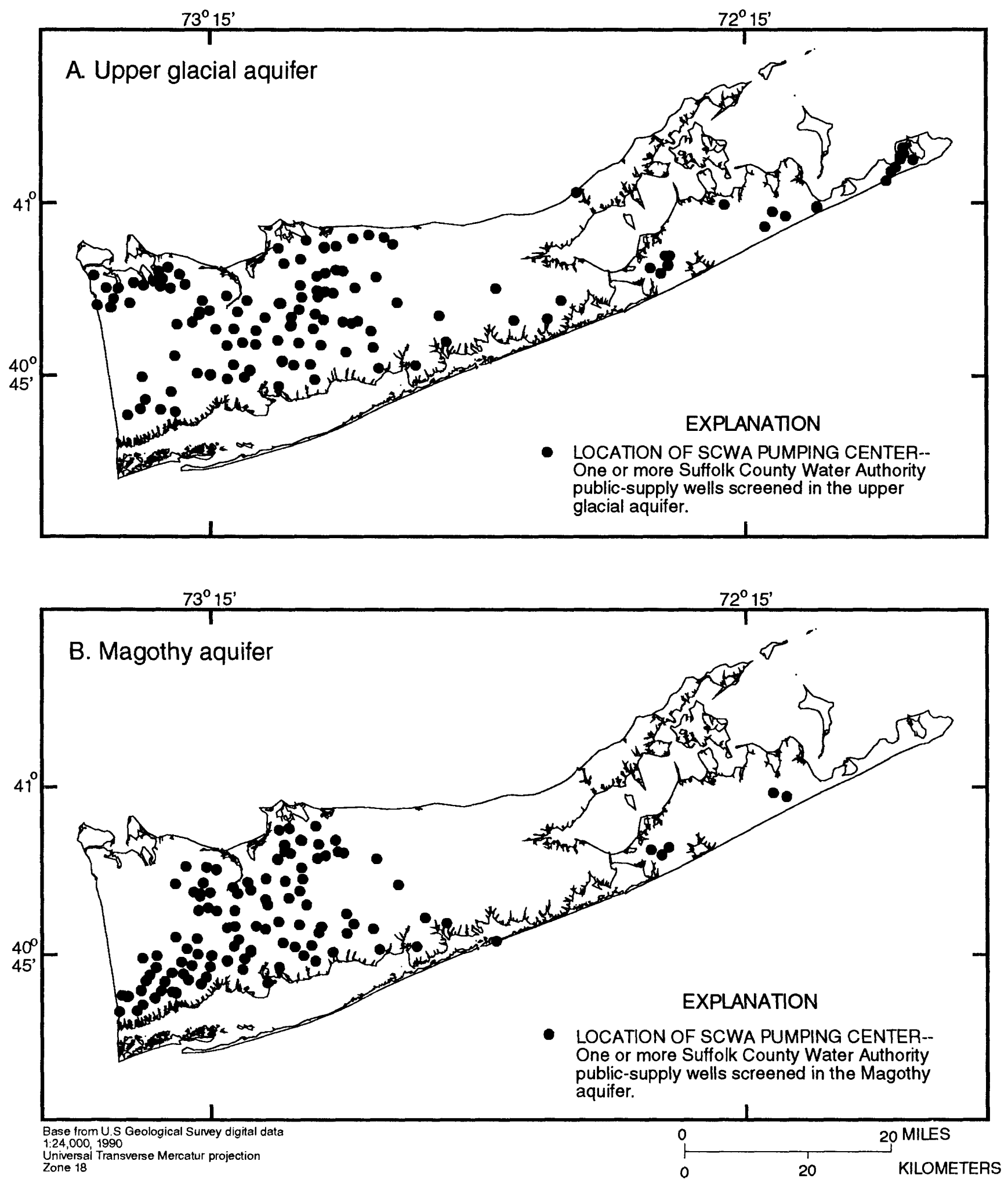

Figure 2. Location of Suffolk County Water Authority (SCWA) pumping centers, Long Island, N.Y., in (A) upper glacial aquifer, and (B) Magothy aquifer. (Location is shown in fig. 1.) 

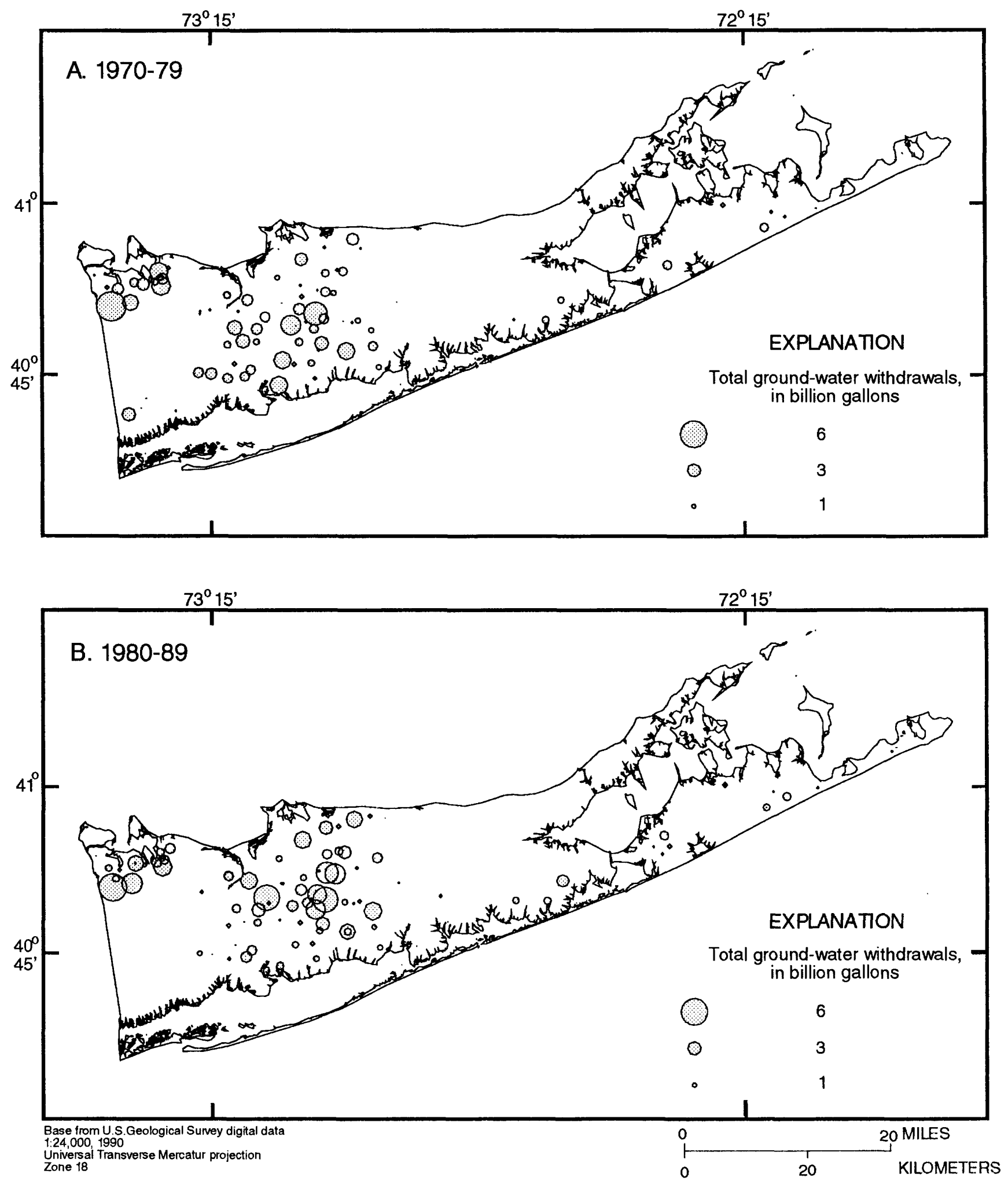

Figure 3. Areal distribution of ground-water withdrawals by the Suffolk County Water Authority from the upper glacial aquifer, Long Island, N.Y., in (A) 1970-79, and (B) 1980-89. 

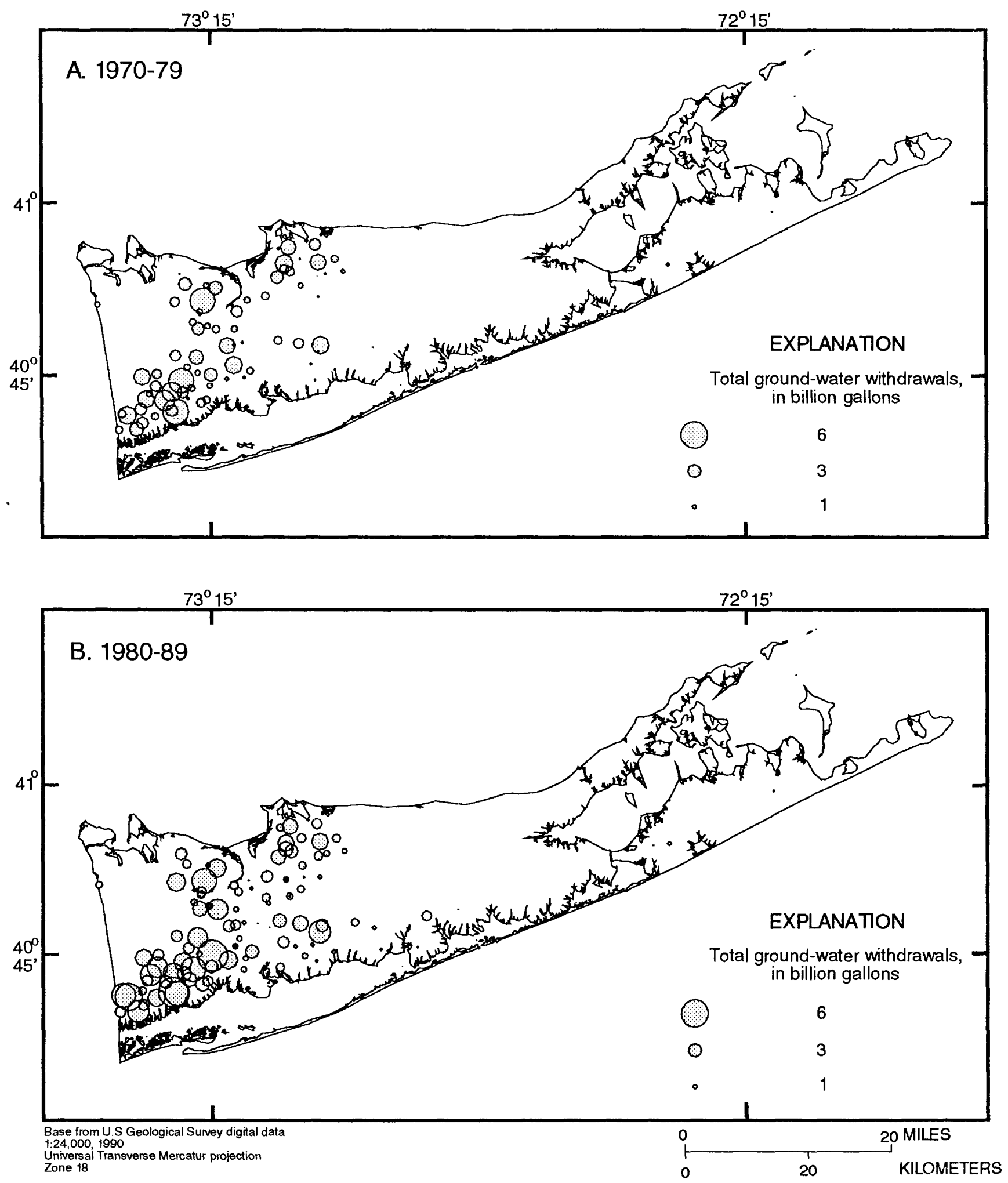

Figure 4. Areal distribution of ground-water withdrawals by the Suffolk County Water Authority from the Magothy aquifer, Long Island, N.Y., in (A) 1970-79, and (B) 1980-89. 

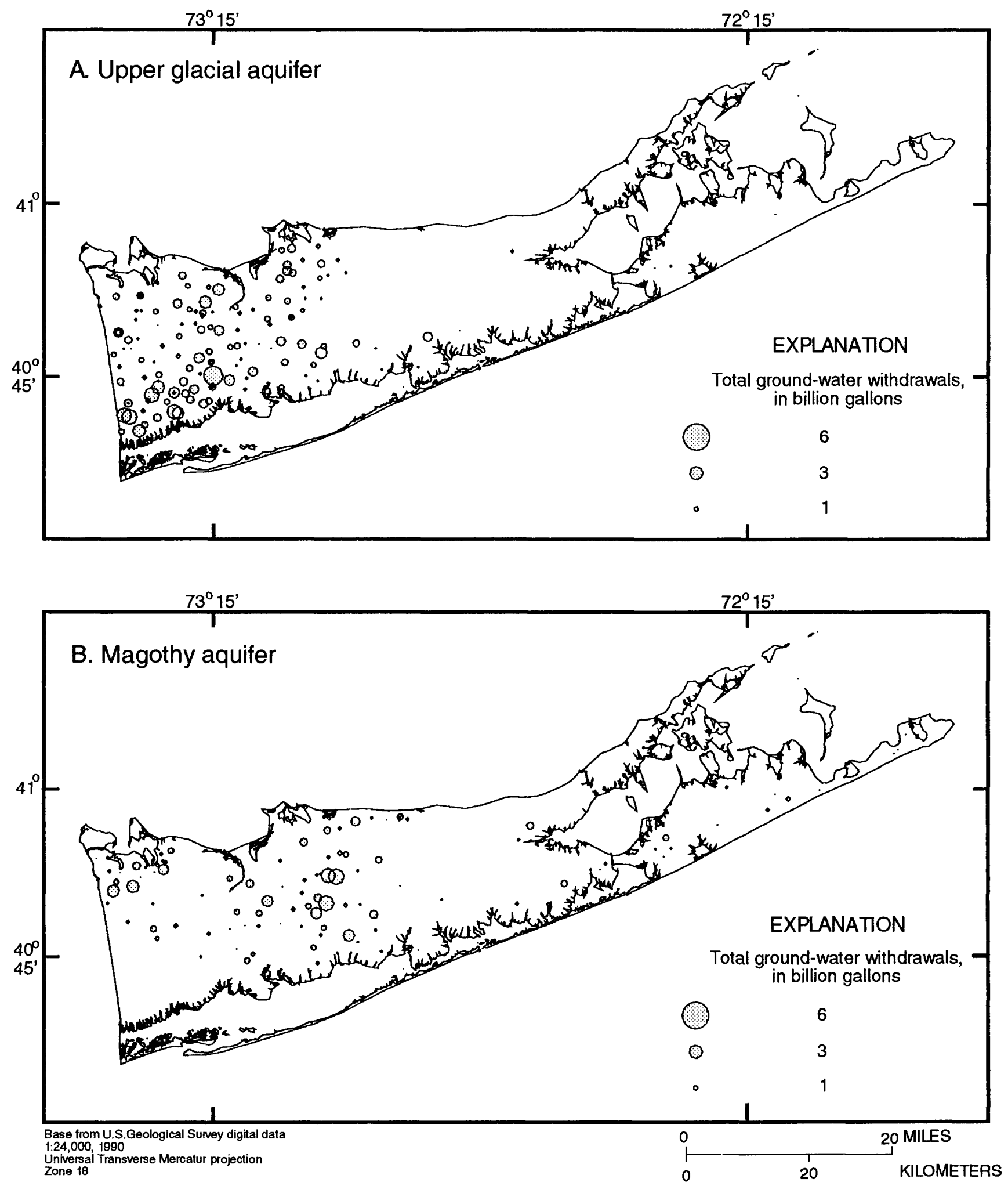

Figure 5. Areal distribution of ground-water withdrawals by all Suffolk County, Long Island, N.Y., water suppliers during 1985-89 from (A) upper glacial aquifer, and (B) Magothy aquifer. 


\section{Acknowledgments}

Thanks are extended to Steven Colabufo of the SCWA for supplying specific-capacity and wellnetwork data, to the NYSDEC for supplying pumpage data, and to SCWA laboratory personnel for supplying water-quality data from SCWA test borings.

\section{HYDROGEOLOGIC SETTING}

Long Island lies at the northern extent of the Atlantic Coastal Plain and consists of unconsolidated Pleistocene and Late Cretaceous sediments underlain by Precambrian(?) crystalline bedrock; the bedrock consists of muscovite-biotite schist, gneiss, and granite of Precambrian(?) age (Smolensky and others,
1989). Suffolk County is in the eastern half of Long Island and encompasses about $1,200 \mathrm{mi}^{2}$ (fig. 1).

\section{Hydrogeologic Framework}

The unconsolidated sediments of Long Island overlie a southeastward dipping bedrock surface and thicken from $0 \mathrm{ft}$ in northwest Queens County to more than 2,000 ft beneath the barrier beach in south-central Suffolk County. The minimum thickness in Suffolk County, about $500 \mathrm{ft}$, is in the northwestern part of the county.

The unconsolidated sediments consist of Pleistocene till, moraine, and outwash deposits overlying Cretaceous nonmarine and deltaic deposits. Characteristics of the major hydrogeologic units in Suffolk County are summarized in table 2 ; the stratigraphy of

Table 2. Generalized description of major hydrogeologic units underlying Suffolk County,N.Y.

[Modified from Jensen and Soren, 1971, table 1]

\begin{tabular}{|c|c|c|}
\hline Hydrogeologic unit & Geologic name & Description and water-bearing characteristics \\
\hline $\begin{array}{l}\text { Upper glacial } \\
\text { aquifer }\end{array}$ & $\begin{array}{l}\text { Holocene and upper } \\
\text { Pleistocene deposits }\end{array}$ & $\begin{array}{l}\text { Mainly brown and gray sand and gravel of moderate to high } \\
\text { hydraulic conductivity; also includes deposits of clayey till and } \\
\text { lacustrine clay of low hydraulic conductivity. A major aquifer. }\end{array}$ \\
\hline Gardiners Clay & Gardiners Clay & $\begin{array}{l}\text { Green and gray clay, silt, clayey and silty sand, and some inter- } \\
\text { bedded clayey and silty gravel; low hydraulic conductivity. Unit } \\
\text { tends to confine water in underlying aquifer. }\end{array}$ \\
\hline $\begin{array}{l}\text { Monmouth } \\
\text { greensand }\end{array}$ & $\begin{array}{l}\text { Monmouth Group, } \\
\text { undifferentiated }\end{array}$ & $\begin{array}{l}\text { Interbedded marine deposits of dark-gray, olive-green, dark- } \\
\text { greenish-gray, and greenish-black glauconitic and lignitic clay, } \\
\text { silt, and clayey and silty sand. Unit has low hydraulic } \\
\text { conductivity and tends to confine water in underlying aquifer. }\end{array}$ \\
\hline Magothy aquifer & $\begin{array}{l}\text { Matawan Group and Magothy } \\
\text { Formation, undifferentiated }\end{array}$ & $\begin{array}{l}\text { Gray and white fine to coarse sand of moderate hydraulic } \\
\text { conductivity. Generally contains sand and gravel beds of low to } \\
\text { high hydraulic conductivity in basal } 100 \text { to } 200 \text { feet. Contains } \\
\text { much interstitial clay and silt, and beds and lenses of clay of low } \\
\text { hydraulic conductivity. A major aquifer. }\end{array}$ \\
\hline Raritan clay & $\begin{array}{l}\text { Unnamed clay member of the } \\
\text { Raritan Formation }\end{array}$ & $\begin{array}{l}\text { Gray, black, and multicolored clay and some silt and fine sand. } \\
\text { Unit has low hydraulic conductivity and tends to confine water } \\
\text { in underlying aquifer. }\end{array}$ \\
\hline Lloyd aquifer & $\begin{array}{l}\text { Lloyd Sand Member of the } \\
\text { Raritan Formation }\end{array}$ & $\begin{array}{l}\text { White and gray fine-to-coarse sand and gravel of moderate } \\
\text { hydraulic conductivity and some clayey beds of low hydraulic } \\
\text { conductivity. }\end{array}$ \\
\hline Bedrock & $\begin{array}{l}\text { Undifferentiated crystalline } \\
\text { rocks }\end{array}$ & $\begin{array}{l}\text { Mainly metamorphic rocks of low hydraulic conductivity; surface } \\
\text { generally weathered; considered to be the bottom of the ground- } \\
\text { water reservoir. }\end{array}$ \\
\hline
\end{tabular}


the hydrogeologic units along a generalized northsouth section near the boundary between Nassau and Suffolk Counties is shown in figure 6 .

\section{Pleistocene Deposits}

Upper Pleistocene sediments underlie all of Suffolk County and unconformably overlie Cretaceous deposits. The maximum thickness of the Pleistocene unit in Suffolk County is about $700 \mathrm{ft}$. The 20 -foot clay is present only along the southwestern shore of Long Island and generally is not an important hydrogeologic unit in Suffolk County. The Smithtown clay is present only in central Suffolk County. The Gardiners Clay extends along the southern shore of most of Long Island; its thickness ranges from 0 to $75 \mathrm{ft}$ (Smolensky and others, 1989).

The upper Pleistocene deposits in northern Long Island consist of sand, gravel, silt, and clay (Smolensky and others, 1989) that form the Harbor Hill and Ronkonkoma terminal moraines (fig. 6). The upper Pleistocene deposits south of the terminal moraines are glacial outwash deposits of sand and gravel with some interbedded silt and clay. The sediments consist

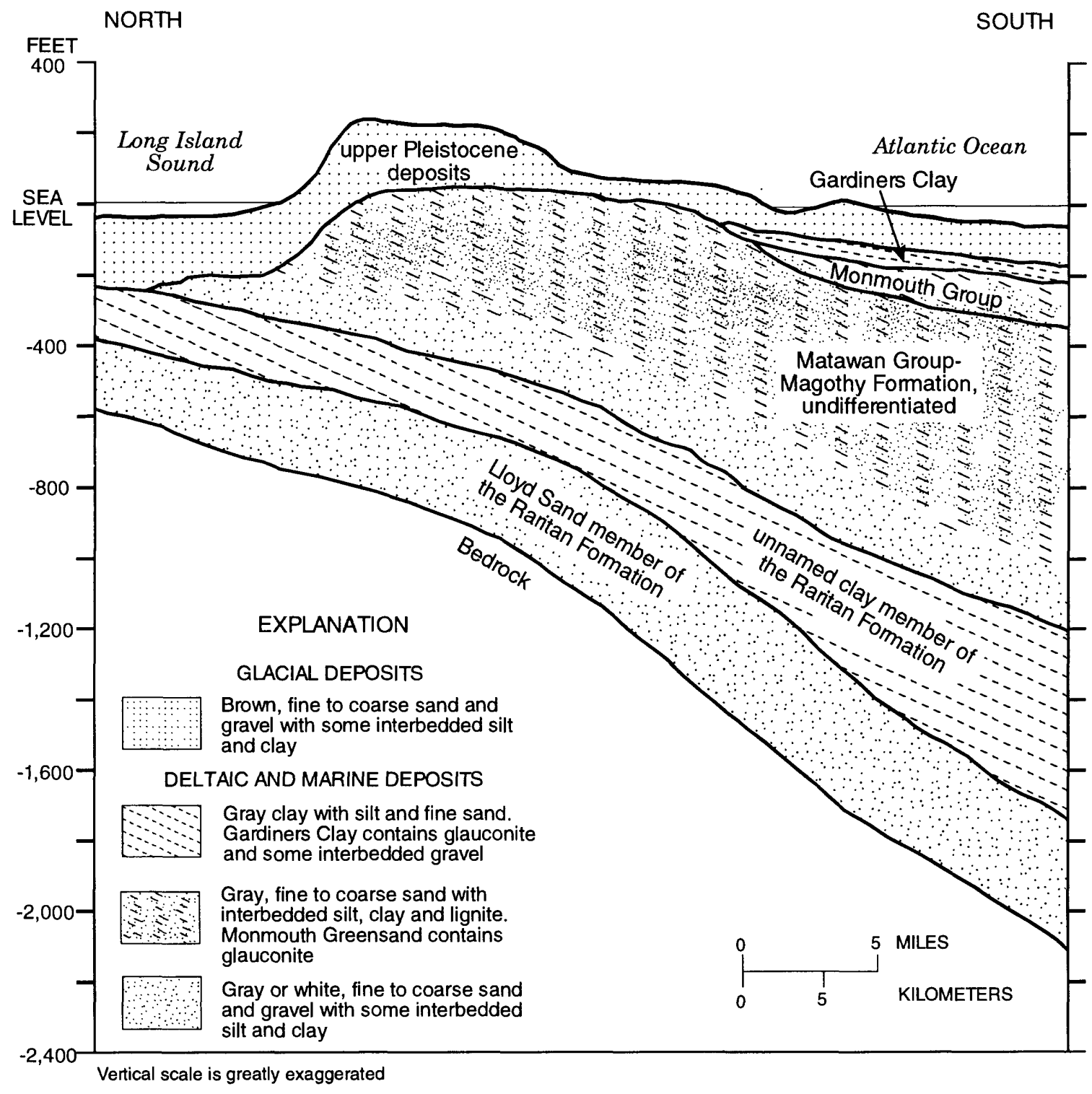

Figure 6. Major hydrogeologic units along a generalized north-south vertical section near the Nassau-Suffolk County border, Long Island, N.Y. (Modified from McClymonds and Franke, 1972, fig. 3.) 
of quartz, feldspar, and rock fragments. Iron oxide stains are common. The unit also contains glaciolacustrine clay lenses (Jensen and Soren, 1974).

\section{Cretaceous Deposits}

The upper surface of the Matawan GroupMagothy Formation, undifferentiated was severely eroded by meltwater streams before Pleistocene deposition. The unit consists of Late Cretaceous nonmarine and deltaic deposits that were part of a system of coalescing deltas (Smolensky and others, 1989). The Matawan Group-Magothy Formation is absent in northwestern Suffolk County, where it was removed by erosion during the Pleistocene; the northern extent of the unit is indicated in figure 8 (further on). The thickness of the unit in Suffolk County ranges from 0 to $1,100 \mathrm{ft}$.

The Magothy Formation consists of gray sand and silt interbedded with clay lenses that generally are gray or black. The sand is fine to medium and contains interstitial silt or clay. A zone of coarse sand and gravel forms the base of the unit. The sand consists mainly of quartz and contains lesser amounts of feldspar, biotite, and rock fragments. Lignite is common and is present as beds and disseminated in the sediments. Pyrite and marcasite are common along the southem shore and commonly are present in association with lignite. The Monmouth greensand of Cretaceous age overlies the Matawan Group-Magothy Formation along the southern shore of Long Island. The unit consists of glauconitic marine clays interbedded with greenish-black lignitic and glauconitic silty or clayey sand. Thickness of the unit ranges from 0 to $200 \mathrm{ft}$ (Smolensky and others, 1989).

The upper surface of the underlying Raritan Formation was eroded before deposition of the Matawan Group-Magothy Formation. The Raritan Formation is divided into the unnamed clay and Lloyd Sand members. It is a deltaic deposit with a depositional history similar to that of the Matawan Group-Magothy Formation, undifferentiated (Smolensky and others, 1989) and underlies all of Suffolk County. The unnamed clay member lies conformably on the Lloyd Sand member and ranges in thickness from 0 to $200 \mathrm{ft}$. The unit consists primarily of clay with interbedded silty sand. Lignite and pyrite are common. The unit is typically gray but can be white or red (Smolensky and others, 1989). The underlying Lloyd Sand member has a maximum thickness of $500 \mathrm{ft}$. The unit consists of medium to coarse quartz sand and gravel with interbedded gray, white, or red clay and contains thin beds of lignite (Smolensky and others, 1989). The Raritan Formation typically is underlain by a zone of weathered bedrock that has a maximum thickness of $70 \mathrm{ft}$.

\section{Ground Water}

The upper Pleistocene and the Matawan GroupMagothy Formation constitute the upper glacial and Magothy aquifers, respectively. The Lloyd Sand member of the Raritan Formation constitutes the Lloyd aquifer, which is not an important source of potable water in Suffolk County. All but four wells in the SCWA well network obtain their water from the upper glacial and Magothy aquifers; the remaining four wells obtain water from the Lloyd aquifer.

\section{Ground-Water Flow}

The upper glacial aquifer is moderately to highly permeable, and the Magothy aquifer is moderately permeable (Smolensky and others, 1989). McClymonds and Franke (1972) reported an average horizontal hydraulic conductivity of $254 \mathrm{ft} / \mathrm{d}$ for the upper glacial aquifer in central Suffolk County and $48 \mathrm{ft} / \mathrm{d}$ for the Magothy aquifer. Smolensky and others (1989) reported average horizontal hydraulic conductivities of 270 and $50 \mathrm{ft} / \mathrm{d}$ for the upper glacial and Magothy aquifers, respectively.

Recharge to the ground-water system is derived solely from precipitation. About 50 percent of total precipitation reaches the water table; the remainder is lost through evapotranspiration and as surface runoff (Warren and others, 1968). Recharge near the coast flows through the upper glacial aquifer in shallow subsystems and discharges to the bays and ocean; farther inland, it enters shallow-flow subsystems that discharge to streams and lakes as well as the surrounding bays and ocean. Precipitation that falls close to the ground-water divide flows downward and recharges the deep aquifers, and water that enters directly at or near the divide flows downward into the Lloyd aquifer. A generalized section showing ground-water-flow patterns in the Long Island aquifer system is shown in figure 7.

The water table is within the upper glacial aquifer throughout Suffolk County. Water in the upper glacial aquifer in central Suffolk County can be locally confined by the Smithtown clay, and water in the Mag- 
NORTH

SOUTH

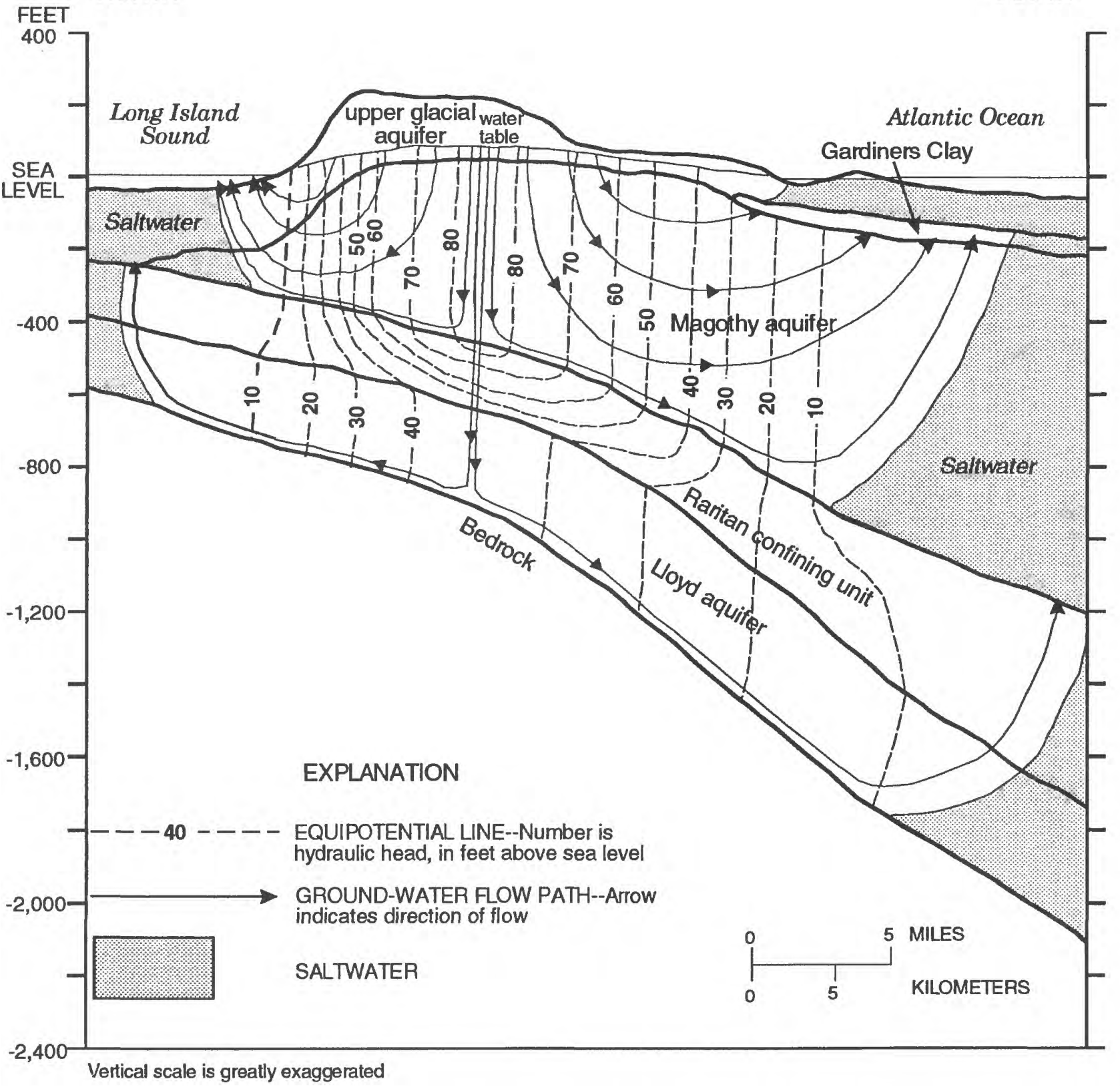

Figure 7. Hydraulic heads and ground-water flow paths along a generalized north-south vertical section near the Nassau-Suffolk County border, Long Island, N.Y. (Modified from Reilly and others, 1983, fig. 4.)

othy aquifer along the southern shore is confined by the Gardiners Clay. Maps of the water table and the potentiometric surface of the Magothy aquifer in March 1991 are shown in figure 8. Mounds in the water table and in the Magothy potentiometric surface are present in western and central Suffolk County. Locations of areas of ground-water recharge and dis- charge on the main body of Long Island are shown in figure 9. The line separating recharge zones from discharge zones in the Magothy aquifer represents the line along which heads in the upper glacial and Magothy aquifers are equal (the component of vertical flow is zero). In discharge zones, the direction of flow is upward, and water flows from the Magothy aquifer 

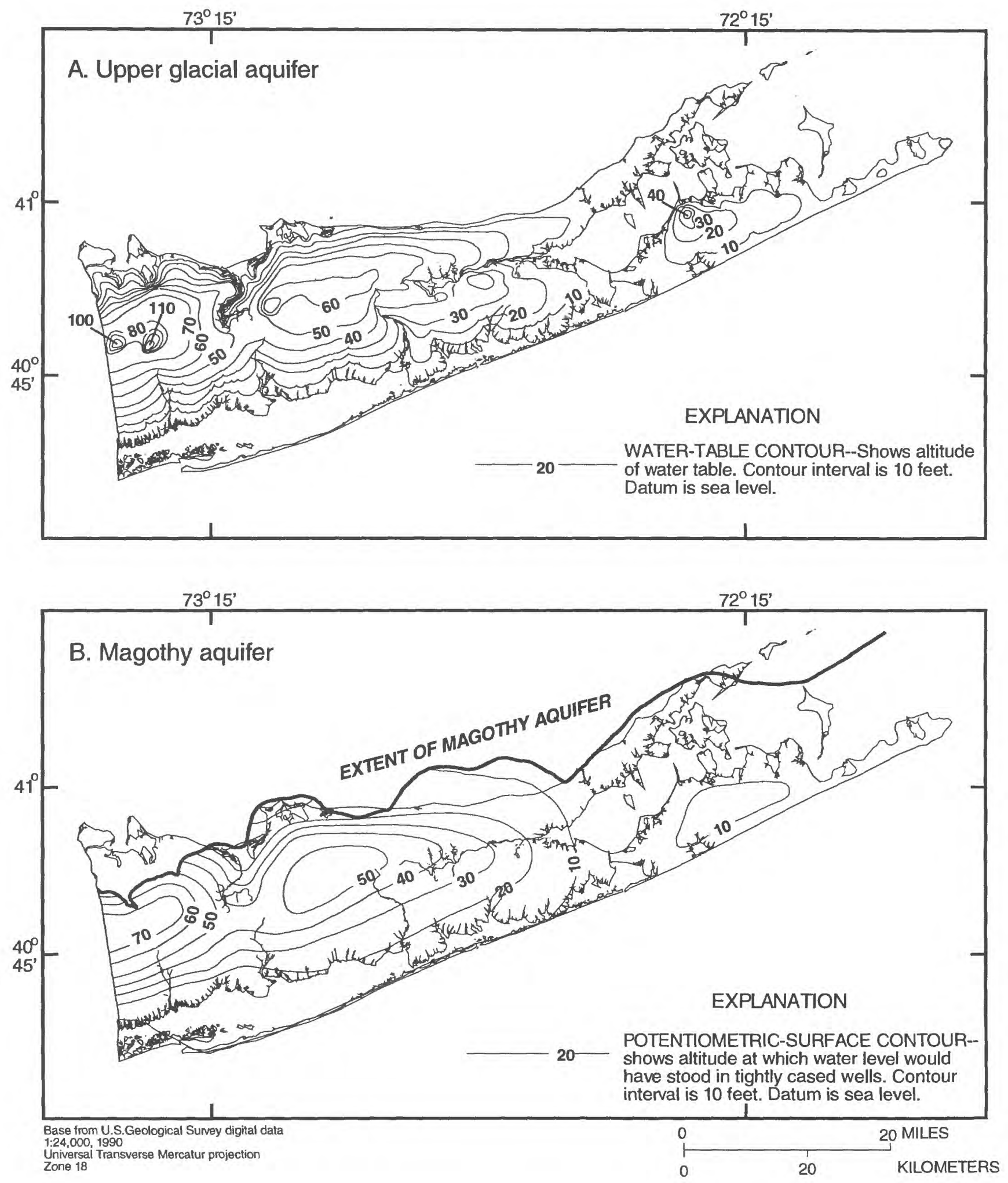

Figure 8. Ground-water levels in Suffolk County, N.Y., March 1991. A. Upper glacial (water-table) aquifer. B. Magothy aquifer. 


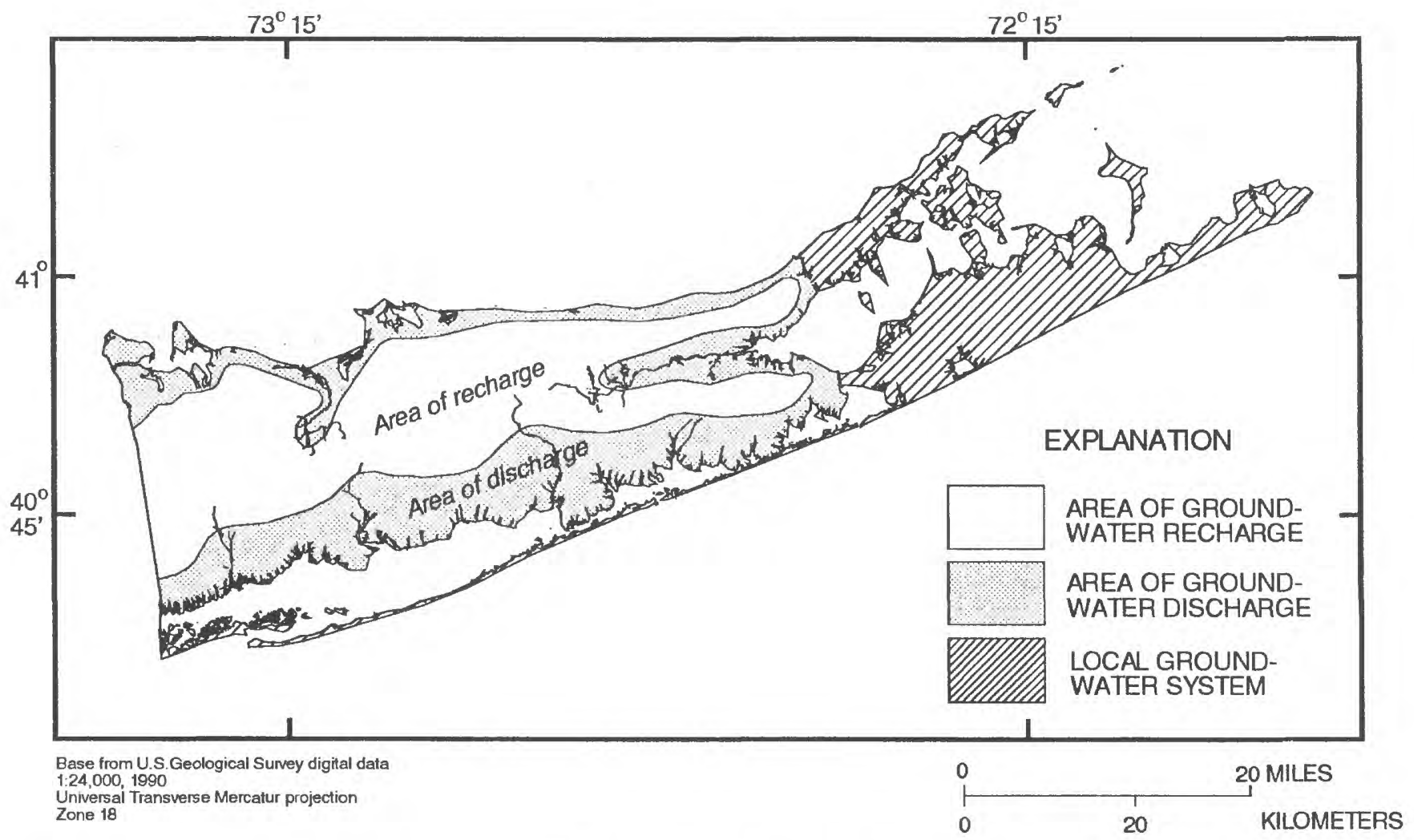

Figure 9. Location of ground-water recharge and discharge areas in Suffolk County, N.Y.

to the upper glacial aquifer. In recharge zones, the direction of flow is downward, and water flows from the upper glacial aquifer to the Magothy aquifer. The locations of the lines indicate that discharge from the Magothy to the upper glacial aquifer occurs primarily along the southern shore and the inland bend between the water-level mounds in the Magothy aquifer.

\section{Ground-Water Quality}

Water quality in the upper glacial and Magothy aquifers is affected by natural and human- related processes. Natural (predevelopment) water quality in Long Island's ground-water system reflects the chemistry of natural precipitation, the mineralogy of the aquifer sediments, and prevailing redox conditions in the ground water. As oxygenated water flows through the aquifer from the water table to areas of discharge, $\mathrm{O}_{2}$ is consumed by the oxidation of organic matter, primarily in the form of lignite, by aerobic bacteria. As oxygen is consumed and conditions become more reducing, nitrate reduction and denitrification occur. After the reduction of nitrate, lignite oxidation, coupled with the reduction and dissolution of manganese and iron oxide coatings, releases $\mathrm{Mn}^{2+}$ and $\mathrm{Fe}^{2+}$ into solution; the process of iron oxide reduction is the cause of highiron environments elsewhere in the Atlantic Coastal Plain (Chapelle and Lovley, 1992). Depletion of available iron oxide allows the reduction of sulfate to sulfide and the subsequent precipitation of authigenic pyrite $\left(\mathrm{FeS}_{2}\right)$. Pyrite is commonly found in association with lignite in fine-grained Magothy aquifer sediments along the southern shore of the island (Steven Colobufo, Suffolk County Water Authority, oral commun.). The oxidation of authigenic pyrite can also be a cause of high-iron environments in the Magothy aquifer; the predominant geochemical processes governing water quality in the Magothy aquifer in Maryland are discussed in Knobel and Phillips (1988).

Native (predevelopment) water quality is difficult to characterize because (1) the effects of human activities are evident in most parts of the upper glacial and Magothy aquifers, and (2) geochemical conditions vary locally, and those in areas of ground-water recharge differ from those in areas of discharge. Native water as described by de Laguna (1964), 
Eckhardt and others (1988), and Pearsall (1996) is summarized in table 3. De Laguna (1964) summarized native quality of ground water in the upper gla-

Table 3. Native water quality in Suffolk County, N.Y., as indicated by data from three previous studies

[All values are medians; concentrations are in milligrams per liter; $<$, less than; dashes indicate no data]

\begin{tabular}{|c|c|c|c|}
\hline \multirow[b]{2}{*}{$\begin{array}{l}\text { Constituent or } \\
\text { characteristic }\end{array}$} & \multicolumn{3}{|c|}{ Data source } \\
\hline & $\begin{array}{l}\text { de Laguna } \\
(1964)^{1}\end{array}$ & $\begin{array}{l}\text { Eckhardt and } \\
\text { others }(1988)^{2}\end{array}$ & $\begin{array}{c}\text { Pearsall } \\
(1996)^{3}\end{array}$ \\
\hline Iron (dissolved) & - & $<0.05$ & $<0.05$ \\
\hline Manganese (dissolved) & -- & $<.05$ & $<.05$ \\
\hline Calcium & 2.0 & 4.0 & 1.2 \\
\hline Magnesium & 1.5 & 1.6 & 0.6 \\
\hline Sodium & 4.0 & 5.0 & 3.3 \\
\hline Potassium & .6 & .8 & .4 \\
\hline Nitrate & .50 & .24 & .20 \\
\hline Sulfate & 8.0 & 9.0 & 1.6 \\
\hline Phosphate & -- & 0.02 & - \\
\hline Chloride & 5.0 & 8.3 & 4.0 \\
\hline Alkalinity (as $\mathrm{CaCO}_{3}$ ) & 7.0 & 7.0 & 6.0 \\
\hline pH (units) & 6.0 & - & - \\
\hline Dissolved solids & 36 & 70 & 25 \\
\hline
\end{tabular}
County.

${ }^{1}$ Upper glacial aquifer in central Suffolk County.

${ }^{2}$ Upper 40 feet of upper glacial aquifer in eastern Suffolk

${ }^{3}$ Lower Magothy aquifer in Suffolk County. cial aquifer in central Suffolk County; Eckhardt and others (1988) summarized the effects of land use on water quality at wells screened within $40 \mathrm{ft}$ of the water table in several areas; and Pearsall (1996) compared the amounts of several major ions derived from human activities in ground water from residential areas with those in ground water from agricultural areas. The data from Pearsall (table 2) are from the lower part of the Magothy aquifer in areas of ground-water recharge in central Suffolk County, and are assumed to be representative of predevelopment conditions.

Data assembled from the USGS WATSTORE database were used to determine the ranges and median concentrations of several constituents that could be related to biofouling in the Magothy and upper glacial aquifers (table 4); the methods used in assembling the data are described further on. The values in table 4 represent only the median values of concentrations stored in the WATSTORE database and thus might not be representative of the true median concentrations at a given well.

\section{IRON-RELATED WELL-SCREEN ENCRUSTATION AND AQUIFER BIOFOULING}

Iron-related well-screen encrustation and biofouling of wells has necessitated the routine recondi-

Table 4. Ranges and median concentrations of selected constituents from NWIS ${ }^{1}$ data base for Magothy and upper glacial aquifers, Long Island, N.Y.

[All concentrations are in milligrams per liter; <, less than]

\begin{tabular}{|c|c|c|c|c|c|c|}
\hline \multirow[b]{2}{*}{ Constituent or characteristic } & \multicolumn{3}{|c|}{ Magothy aquifer } & \multicolumn{3}{|c|}{ Upper glacial aquifer } \\
\hline & Minimum & Median & Maximum & Minimum & Median & Maximum \\
\hline Total iron & $<0.01$ & 0.27 & 8.5 & $<0.01$ & 0.15 & 40 \\
\hline Dissolved iron & $<.003$ & .08 & 8.8 & $<.003$ & .2 & 40 \\
\hline Total manganese & $<.01$ & .02 & .52 & $<.01$ & .03 & 11 \\
\hline Dissolved manganese & $<0.00$ & .01 & .86 & $<.001$ & .06 & 22 \\
\hline Dissolved sulfate & $<.2$ & 3.0 & 72 & $<.2$ & 12 & 2,600 \\
\hline Nitrate (as N) & $<.01$ & .08 & 8.7 & $<.01$ & 2.2 & 49 \\
\hline Total phosphate & $<.10$ & .13 & 2.0 & $<.06$ & .03 & 37 \\
\hline Dissolved oxygen & $<.3$ & 3.1 & 12 & $<1.0$ & 7.0 & 12 \\
\hline Total alkalinity & 1 & 10 & 63 & 1 & 13 & 325 \\
\hline $\mathrm{pH}$ (units) & 4.7 & 6.0 & 8.5 & 4.4 & 6.0 & 8.6 \\
\hline
\end{tabular}

${ }^{1}$ U.S. Geological Survey National Water Information System 
tioning, redrilling, and replacement of affected wells. From October 1990 through September 1992, the SCWA abandoned and replaced 12 wells, reconditioned 56 wells, and redrilled 3 wells.

The most common reconditioning procedure is to (1) remove the pump and treat the screen with sulfamic acid, which remains in the casing for 72 hours, (2) surge the well to remove encrusting and biofouling material, (3) pump the well until all acid has been removed and ambient water quality is observed, and (4) test the specific capacity to ensure that recovery has been successful. Poor recoveries require a second acid treatment. If recovery is sufficient, the pump column is steam cleaned and replaced, and the well operation is resumed. If the recovery is inadequate, well casings may be removed, and the borehole redrilled to remove biofouled gravel packs.

\section{Effect of Iron Biofouling on Specific Capacity of Wells}

The specific capacity $(\mathrm{Sc})$ of a well is a function of the hydraulic conductivity of the surrounding gravel pack and formation, the well-screen slot size, well diameter, and flow rate. The $S c$ is determined by the equation

$$
S c=Q / \Delta h,
$$

where $Q$ is the discharge of the well (volume per time unit) and $\Delta h$ is the change in head. Specific capacity commonly is given in units of gallons per minute per foot of drawdown. Initial specific-capacity measurements are made after the installation of new wells, and subsequent measurements are made annually to monitor well efficiency. Wells with a rapidly declining specific capacity are selected for reconditioning. In this study, specific-capacity measurements for 357 of the SCWA's wells through 1990 were obtained from the SCWA Engineering Department (data from an additional 52 wells were incomplete) and used to calculate average specific-capacity declines. The medians, means, standard deviations, and ranges of initial specific capacities for the upper glacial and Magothy aquifer wells, and specific-capacity decreases, are presented in table 5.

The initial specific capacity of a well is a function of the hydraulic conductivity of the gravel pack and the surrounding formation before any biofouling of the screen and gravel pack. Histograms showing the
Table 5. Specific-capacity data from 357 Suffolk County Water Authority wells, Suffolk County, N.Y., 1990-92

[Sc, specific capacity; Sc values are in gallons per minute per foot of drawdown]

\begin{tabular}{|c|c|c|c|c|c|c|}
\hline \multirow[b]{2}{*}{ Statistic } & \multicolumn{3}{|c|}{$\begin{array}{l}\text { Magothy aqulfer } \\
\text { (200 wells) }\end{array}$} & \multicolumn{3}{|c|}{$\begin{array}{c}\text { Upper glaclal aqulfer } \\
\text { (157 wells) }\end{array}$} \\
\hline & $\begin{array}{c}\text { Inlt|al } \\
\text { Sc }\end{array}$ & $\begin{array}{c}\text { Percent } \\
\text { total } \\
\text { decrease }\end{array}$ & $\begin{array}{l}\text { Percent } \\
\text { annual } \\
\text { decrease }\end{array}$ & $\begin{array}{l}\text { Inltial } \\
\text { Sc }\end{array}$ & $\begin{array}{l}\text { Percent } \\
\text { total } \\
\text { decrease }\end{array}$ & $\begin{array}{l}\text { Percent } \\
\text { annual } \\
\text { decrease }\end{array}$ \\
\hline Mean & 44.5 & 21 & 3.4 & 61.5 & 24 & 3.0 \\
\hline Median & 41.2 & 20 & 1.4 & 51.3 & 22 & 1.5 \\
\hline Minimum & 8.3 & -48 & -16 & 5.4 & -33 & -5.5 \\
\hline Maximum & 150 & 69 & 47 & 229 & 85 & 33 \\
\hline $\begin{array}{l}\text { Standard } \\
\text { deviation }\end{array}$ & 18.9 & 21 & 7.6 & 37.3 & 23 & 4.9 \\
\hline
\end{tabular}

statistical distribution of initial specific capacities of 157 wells screened in the upper glacial aquifer and 200 wells screened in the Magothy aquifer are shown in figures 10A and 10D. The data indicate that initial specific capacities of wells screened in the upper glacial aquifer were higher and had a wider range than those of wells screened in the Magothy aquifer; the higher hydraulic conductivity of the upper glacial aquifer could be the reason.

Decreases in specific capacities of the wells were calculated from current and initial specificcapacity data. For wells with a history of reconditioning, specific-capacity changes between each reconditioning procedure were averaged. The statistical distribution of specific-capacity decreases in the Magothy and upper glacial aquifers is shown in figures $10 \mathrm{~B}$ and 10E. Decreases of less than 0 percent (negative values in the graphs) indicate specific-capacity increases and can be attributed to the removal of fine particles by continued pumping of the wells or to corrosion of the well screens and the subsequent widening of screen slots. A total of 23 Magothy aquifer wells and 18 upper glacial aquifer wells had specificcapacity increases. The percentage of wells with specific-capacity increases is 12 percent for both aquifers.

The data show that total specific-capacity decreases in both aquifers ranged widely and had similar mean and median values. Specific-capacity decreases in the upper glacial aquifer ranged from 0 to 85 percent. The median decrease was 22 percent, the mean decrease was 24 percent, and the standard deviation was 23 . Specific-capacity decreases in the Magothy aquifer ranged from 0 to 69 percent. The median 


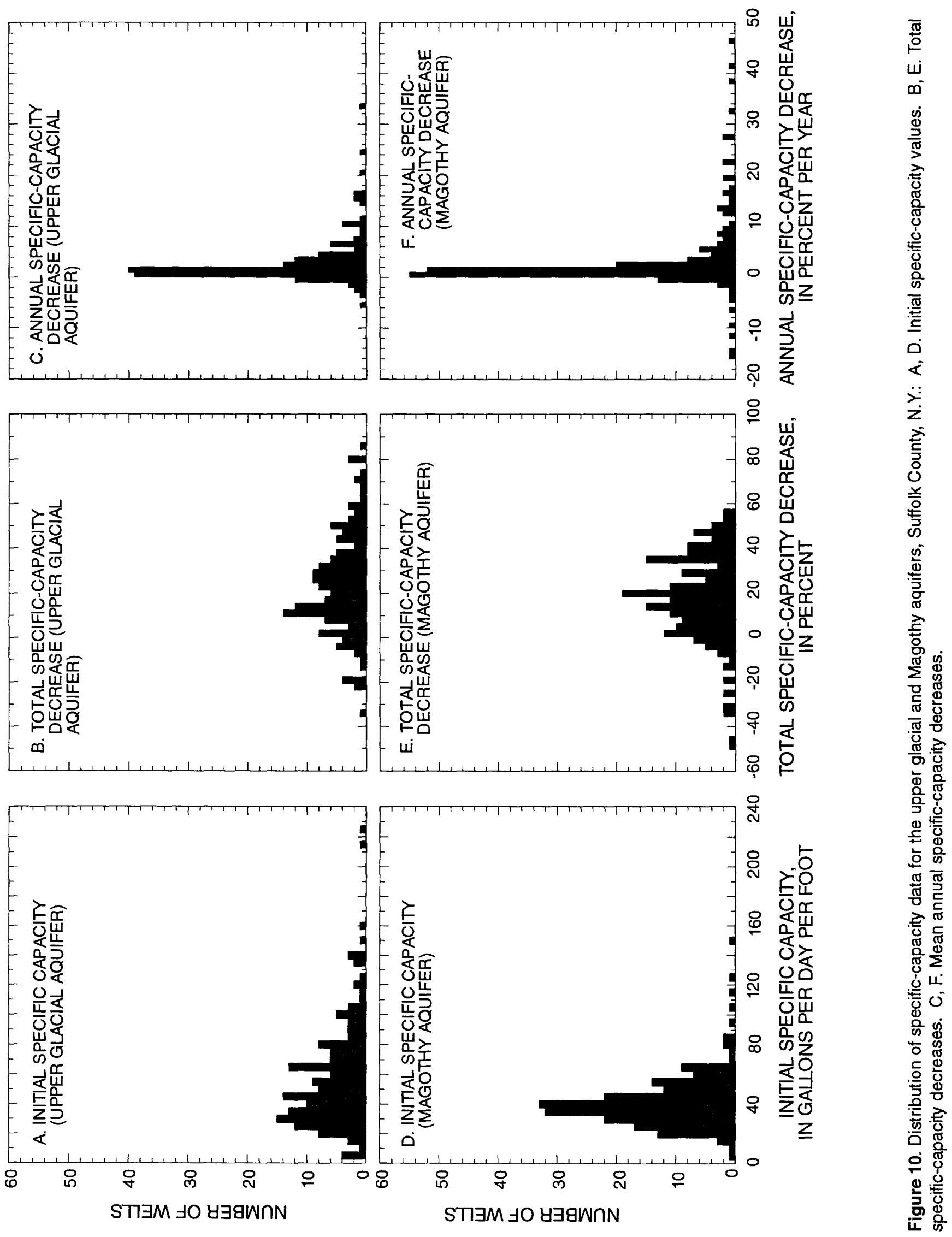


and mean for specific-capacity decreases in the Magothy aquifer were 20 and 22 percent, respectively, and the standard deviation was 21 .

The average annual specific-capacity decreases of the 357 wells were estimated by normalizing total specific-capacity decreases to operating time. The statistical distribution of annual specific-capacity decreases (in percent) for the two aquifers is shown in figures $10 \mathrm{C}$ and 10F. Annual specific-capacity decreases for upper glacial aquifer wells ranged from -5.5 to 33 percent per year; the median and mean annual decreases were 3.0 and 1.5 percent, respectively, and the standard deviation was 4.9. Annual decreases in the Magothy aquifer ranged from 0 to 47 percent; the median and mean annual decreases were 1.4 and 3.4 percent, respectively, and the standard deviation was 7.6. The histograms (fig. 10) indicate that the annual rates of specific-capacity decrease were similar in both aquifers.

In this study, an average annual specificcapacity decrease of 5 percent was used to separate "unaffected" wells from "affected" wells. The 5.0-percent value is based on the statisticai distribution of specific-capacity decreases (figs. 10E, 10F). Annual decreases greater than 5.0 percent are assumed to differ significantly from the remaining population; the percentage of upper glacial and Magothy aquifer wells with average annual specific-capacity decreases between 0 and 5.0 percent was 73 and 70 percent, respectively. Of the 200 Magothy aquifer wells, 37 (19 percent) had annual specific-capacity decreases greater than 5.0 percent, and, of the 157 upper glacial aquifer wells, 25 (16 percent) had annual specificcapacity decreases greater than 5.0 percent.

\section{Spatial Distribution of Affected Wells}

The specific-capacity data were entered into a Geographic Information System (GIS) data base, which was then used to identify spatial trends among wells with large annual specific-capacity decreases (greater than 5.0 percent per year). The spatial distribution of affected wells and of chemical constituents related to biofouling could be useful in future well siting. The locations of Magothy aquifer and upper glacial aquifer wells with annual specific-capacity decreases greater than and less than 5 percent per year are shown in figure 11; locations of other water suppliers' wells in western Suffolk County are included to compensate for the lack of data in the west-central part of the county. The other water suppliers have reported no iron-related specific-capacity declines; thus, their wells are classified as unaffected.

Upper glacial aquifer wells with an average annual specific-capacity decrease of greater than 5.0 percent per year are mostly in south-central Suffolk County (fig. 11A). Their location between the water-table mounds delineated in figure $8 \mathrm{~A}$ suggests that affected upper glacial aquifer wells are associated with ground-water discharge zones. The distribution of affected upper glacial aquifer wells is similar to that of affected Magothy aquifer wells. Few SCWA wells are screened in the upper glacial aquifer in the populated sections of southwestern Suffolk County, where several Magothy aquifer wells are affected.

Magothy aquifer wells with specific-capacity decreases greater than 5.0 percent per year are mostly along the southern shore and in central Suffolk County (fig. 11B). Many of the affected Magothy aquifer wells in central Suffolk County are between the two groundwater mounds in the Magothy aquifer, in or near the area of ground-water discharge shown in figure 9. Magothy aquifer wells classified as unaffected are distributed throughout the western half of the county, whereas most of the affected wells are primarily in south-shore discharge zones. The geochemical reasons for this are discussed later.

\section{Relation of Ground-Water Quality to Specific- Capacity Decreases}

Water-quality data bases were assembled to evaluate water-quality differences between unaffected and affected wells. SCWA wells that had annual specific-capacity decreases of less than 5 percent and a history of reconditioning were included with the affected-well group. This classification resulted in a total of 64 affected Magothy aquifer wells and 46 affected upper glacial aquifer wells. Data bases for unaffected and affected wells were assembled from the National Water Information System (NWIS) data base. A total of 5,119 analyses were assembled for unaffected and affected Magothy aquifer wells, and 3,999 analyses were assembled for unaffected and affected upper glacial aquifer wells. Medians for the selected water-quality constituents were computed for each well. Medians for wells with censored data were computed by using the computer program AUTOMDL 

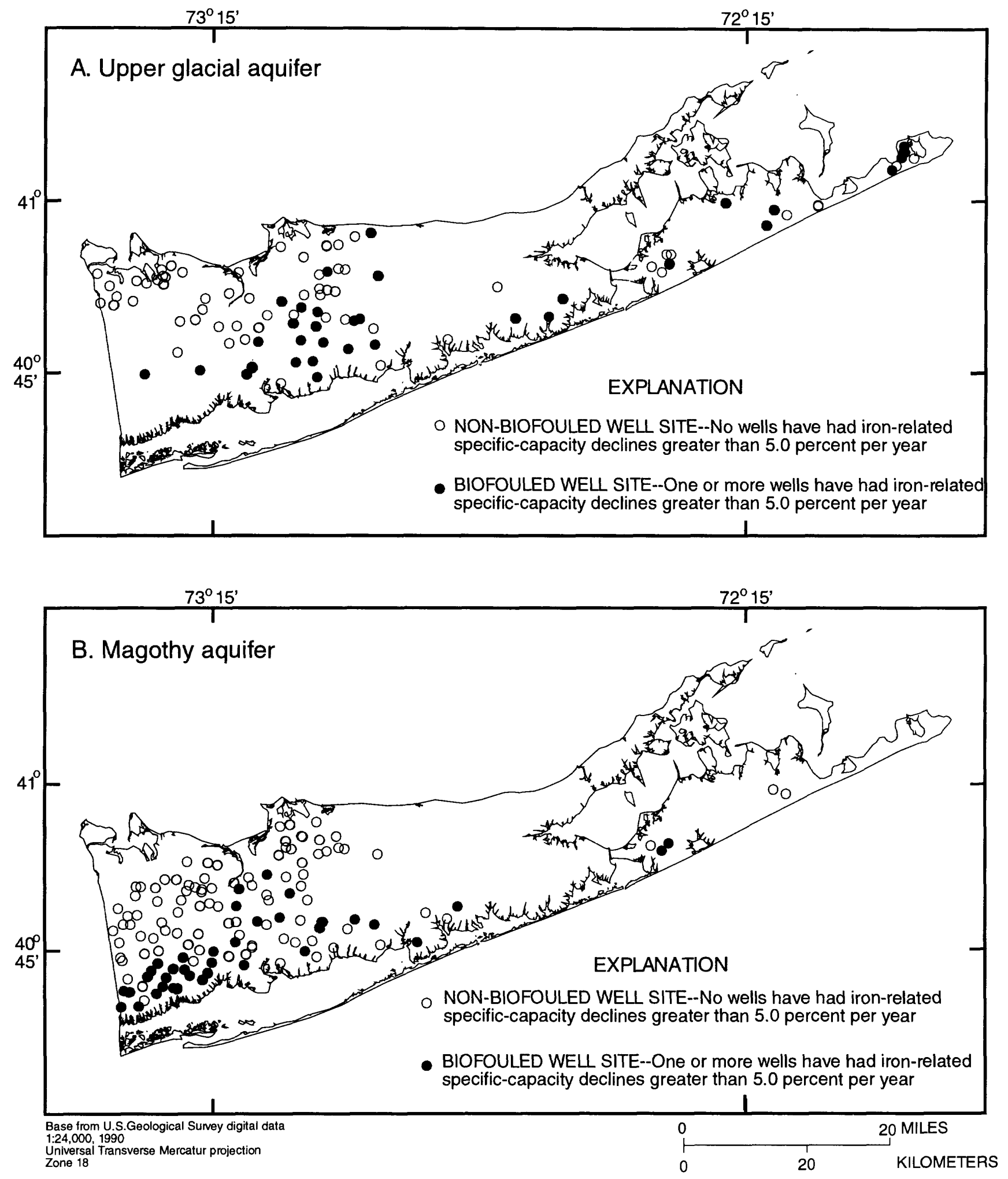

Figure 11. Areal distribution of wells with iron-related specific-capacity declines in Suffolk County, N.Y., in (A) upper glacial aquifer, and (B) Magothy aquifer. 
(Helsel and Cohn, 1988), which uses log-probability regression and maximum-likelihood methods to compute descriptive statistics for data sets containing multiple detection limits. Wells for which reliable medians could not be computed were omitted from the data sets. The nonparametric Mann-Whitney rank sum test was used to test for differences between unaffected and affected wells. A p-value $(\alpha)$ of 0.05 was used to identify significant statistical differences between the two groups of wells for each constituent at a confidence interval of 95 percent. Wherever the number of nondetections exceeded 30 percent in either group, additional tests were done with contingency tables, which provide a measure of association between variables.

Results of the statistical tests for affected and unaffected upper glacial aquifer wells are presented in table 6A. Statistically significant differences between unaffected and affected wells were found only for total and dissolved manganese, dissolved sulfate, and $\mathrm{pH}$. The Mann-Whitney p-values for the remaining constituents were less than 0.05 , indicating no statistical differences in total and dissolved iron, nitrate, phosphate, total sulfate, and field alkalinity between the two groups of upper glacial aquifer wells.

Results of the statistical tests for unaffected and affected Magothy aquifer wells are summarized in table 6B. All constituents tested differed significantly between the two groups of wells, and Mann-Whitney tests gave p-values less than 0.00001 (which indicates significant differences between unaffected and affected wells) for total iron, total manganese, nitrate, sulfate, dissolved oxygen, and $\mathrm{pH}$. Tests for dissolved iron and total field alkalinity gave p-values of 0.001 and 0.0001 , respectively. The largest $p$-values were for phosphate and dissolved manganese $(0.002$ and 0.0179 , respectively); $p$-values from contingency tables for these constituents were less than 0.001 and less than 0.05, respectively. Medians for the constituents in the two groups of wells screened in the Magothy are included in table $6 \mathrm{~B}$.

The difference in concentration of a particular constituent between unaffected and affected wells is not necessarily due to the biofouling process. Average specific-capacity decreases greater than 5 percent per year at wells in discharge zones could cause spurious correlation between large specific-capacity decreases and high concentration of constituents found naturally in discharge zones even without a direct relation. The spatial distributions of major constituents and their possible role in the biofouling process are discussed in the next section.

\section{Spatial Distribution of Selected Chemical Constituents and Properties}

Water-quality data for 1970-90 on constituents of possible significance to the biofouling process were assembled from the WATSTORE data base. The assembled data include 13,632 analyses from 858 observation wells and supply wells screened in the upper glacial aquifer and 8,706 analyses from 356 observation wells and supply wells screened in the Magothy aquifer. All data were collected and analyzed by the USGS or by laboratories in Suffolk County that follow recommended sampling procedures and participate in USGS quality-assurance programs. Medians were computed for each individual well and entered into a GIS data base. Medians for wells with censored data were computed through AUTOMDL. Wells for which reliable medians could not be computed were omitted from the GIS data bases. Additional data on total iron and manganese were obtained from the SCWA test-boring program and used to construct an additional GIS data base. Water-quality analyses for an additional 330 test zones from 119 test boreholes were assembled. A total of 265 water-quality data points were added to the Magothy data base, and 65 data points were added to the upper glacial data base. The GIS data bases were used to identify spatial trends of major constituents. No clear spatial trends were observed in data from the upper glacial aquifer. Maps showing the distribution of selected constituents in the Magothy aquifer are shown in figures $12 \mathrm{~A}-12 \mathrm{H}$. The importance of the geochemical processes discussed below, particularly in relation to iron, manganese, oxygen, phosphorus, sulfate, and $\mathrm{pH}$ in the biofouling process in Suffolk County, is addressed in a companion report describing the site-specific component of the study (Walter, in press).

\section{Iron}

Total or unfiltered iron concentrations greater than $0.5 \mathrm{mg} / \mathrm{L}$ in wells screened in the Magothy aquifer (fig. 12A) are found primarily along the southem shore and in central and east-central Suffolk County; dissolved-iron concentrations above $0.25 \mathrm{mg} / \mathrm{L}$ follow 
Table 6. Statistical summary of water-quality data from unaffected and affected wells in Suffolk County, N.Y.

[Median values of values of all constituents in milligrams per liter; $<$, less than;

$>$, greater than; dashes indicate no data]

\begin{tabular}{|c|c|c|c|c|c|c|}
\hline \multirow[b]{2}{*}{ Constituent or characteristic } & \multicolumn{2}{|c|}{ Unaffected wells } & \multicolumn{2}{|c|}{ Affected wells } & \multirow[b]{2}{*}{$\begin{array}{c}\text { Mann-Whitney } \\
\text { p-value }\end{array}$} & \multirow[b]{2}{*}{$\begin{array}{c}\text { Chi-squared } \\
\text { p-value }\end{array}$} \\
\hline & $\begin{array}{l}\text { Number } \\
\text { of wells }\end{array}$ & Median & $\begin{array}{l}\text { Number } \\
\text { of wells }\end{array}$ & Median & & \\
\hline \multicolumn{7}{|c|}{ A. UPPER GLACIAL AQUIFER } \\
\hline Total iron & 101 & 0.015 & 43 & 0.014 & 0.7683 & -- \\
\hline Dissolved iron & 11 & 0.005 & 17 & 0.007 & 0.3486 & $>0.1$ \\
\hline Total manganese & 87 & 0.004 & 42 & 0.020 & $<0.00001$ & -- \\
\hline Dissolved manganese & 11 & 0.003 & 15 & 0.030 & $<0.00001$ & $<0.001$ \\
\hline Dissolved sulfate & 108 & 6.70 & 45 & 9.35 & 0.0006 & -- \\
\hline Nitrate & 108 & 1.507 & 45 & 2.36 & 0.1379 & -- \\
\hline Total phosphate & 61 & 0.042 & 21 & 0.027 & 0.2362 & $>0.1$ \\
\hline Dissolved oxygen & 13 & 10.00 & 19 & 9.40 & 0.7735 & -- \\
\hline Total alkalinity & 83 & 14.00 & 38 & 13.00 & 0.1267 & -- \\
\hline $\mathrm{pH}$ (units) & 83 & 6.20 & 38 & 6.00 & 0.0126 & -- \\
\hline \multicolumn{7}{|c|}{ B. MAGOTHY AQUIFER } \\
\hline Total iron & 128 & 0.023 & 60 & 0.300 & $<0.00001$ & -- \\
\hline Dissolved iron & 33 & 0.009 & 24 & 0.225 & 0.001 & -- \\
\hline Total manganese & 105 & 0.005 & 57 & 0.010 & $<0.00001$ & -- \\
\hline Dissolved manganese & 31 & 0.002 & 24 & 0.013 & 0.0179 & $<0.05$ \\
\hline Dissolved sulfate & 132 & 2.10 & 61 & 3.30 & $<0.00001$ & -- \\
\hline Nitrate & 116 & 0.263 & 36 & 0.005 & $<0.00001$ & -- \\
\hline Total phosphate & 70 & 0.082 & 49 & 0.565 & 0.0002 & $<0.001$ \\
\hline Dissolved oxygen & 43 & 8.000 & 29 & 0.500 & $<0.00001$ & -- \\
\hline Total alkalinity & 93 & 10.000 & 49 & 4.000 & 0.0001 & -- \\
\hline $\mathrm{pH}$ (units) & 95 & 6.08 & 49 & 5.40 & $<0.00001$ & -- \\
\hline
\end{tabular}

a similar trend. Comparison of the total- and dissolvediron concentration maps (fig. 12A, 12B) with the location of discharge areas (fig. 9) suggests that elevated total- and dissolved-iron concentrations in the Magothy aquifer are in or near discharge zones. Water in discharge zones has interacted with the aquifer material for a longer time than in recharge areas, and the consumption of $\mathrm{O}_{2}$ by the bacterially mediated oxidation of lignite has resulted in an anoxic (reducing) environment. As water moves along a flow path, consumption of $\mathrm{O}_{2}$ and the subsequent reduction of iron oxyhydroxides releases ferrous iron into solution. The microbially mediated reduction of $\mathrm{Fe}^{3+}$ oxides (Chapelle and Lovley, 1992) and the oxidation of authigenic pyrite (Kno- bel and Phillips, 1988) explain the presence of highiron environments elsewhere in the Atlantic Coastal Plain. These processes would be expected to increase iron concentrations along flow paths and can explain the elevated iron concentrations in discharge zones.

Elevated concentrations of ferrous iron facilitate the growth of iron-oxidizing bacteria by providing an energy source for the autotrophic iron bacteria commonly found in biofouled wells (Cullimore, 1986). The inorganic precipitation of iron oxyhydroxides at the anoxic-oxic interface also contributes larger volumes of iron oxide precipitate in wells with elevated iron concentrations than in wells characterized by lower concentrations of dissolved ferrous iron. This 

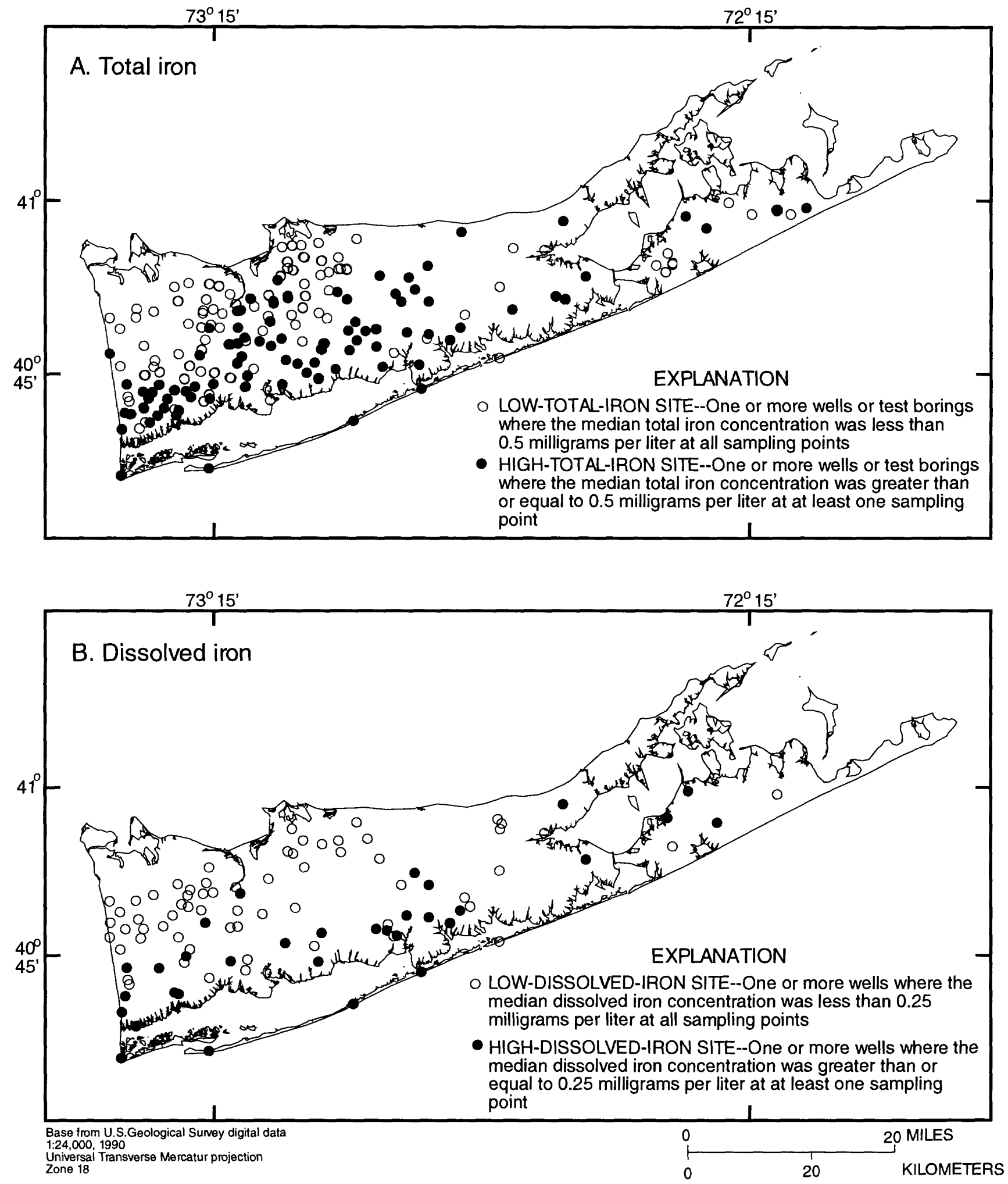

Figure 12. Areal distribution of median values of selected constituents in wells screened in the Magothy aquifer, Suffolk County, N.Y. A. Total iron concentrations greater than 0.5 milligrams per liter. B. Dissolved iron concentrations greater than 0.25 milligrams per liter. 

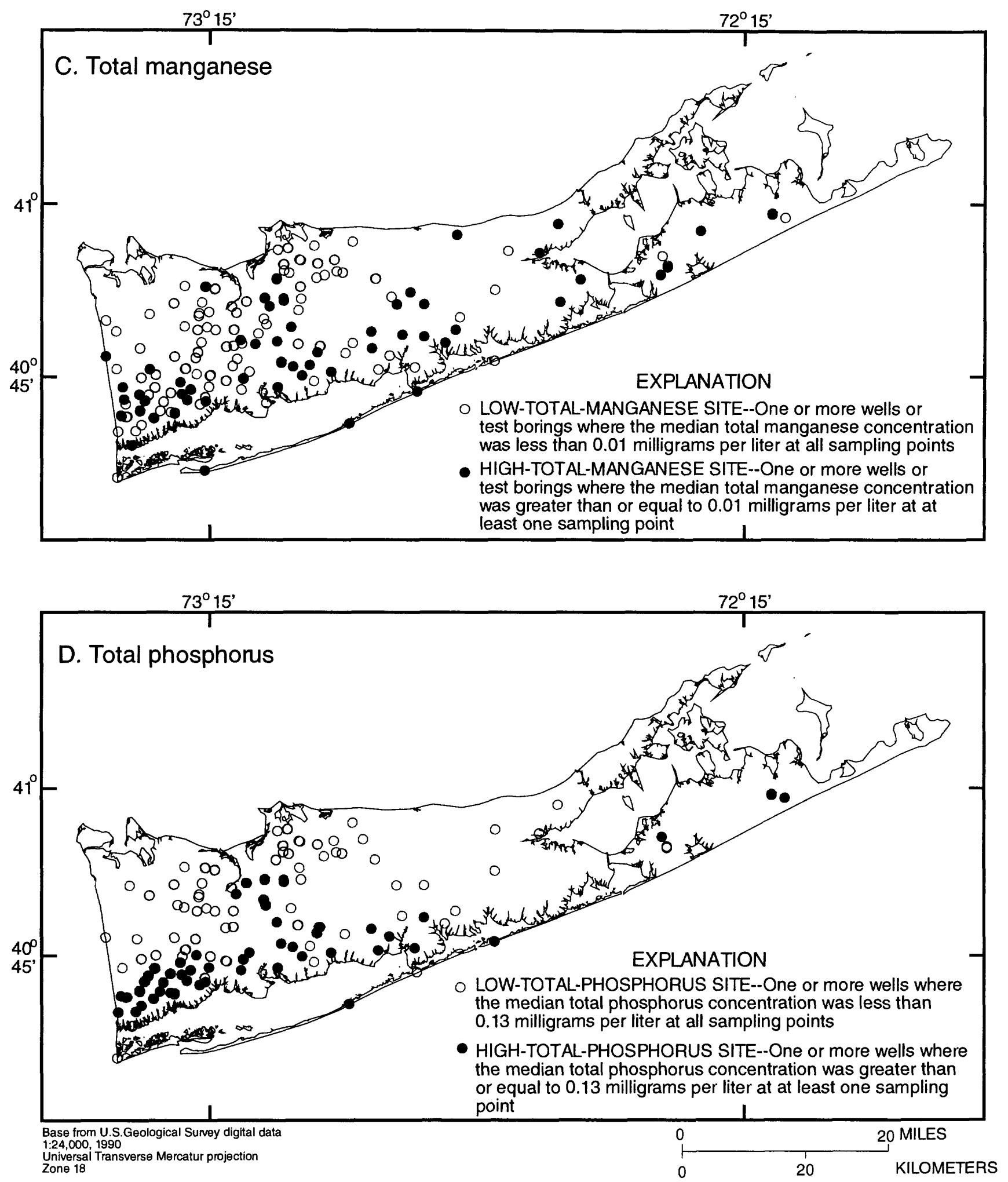

Figure 12 continued. Areal distribution of median values of selected constituents in wells screened in the Magothy aquifer, Suffolk County, N.Y. C. Total manganese concentrations greater than 0.01 milligrams per liter. D. Total phosphate concentration greater than 0.13 milligrams per liter. 

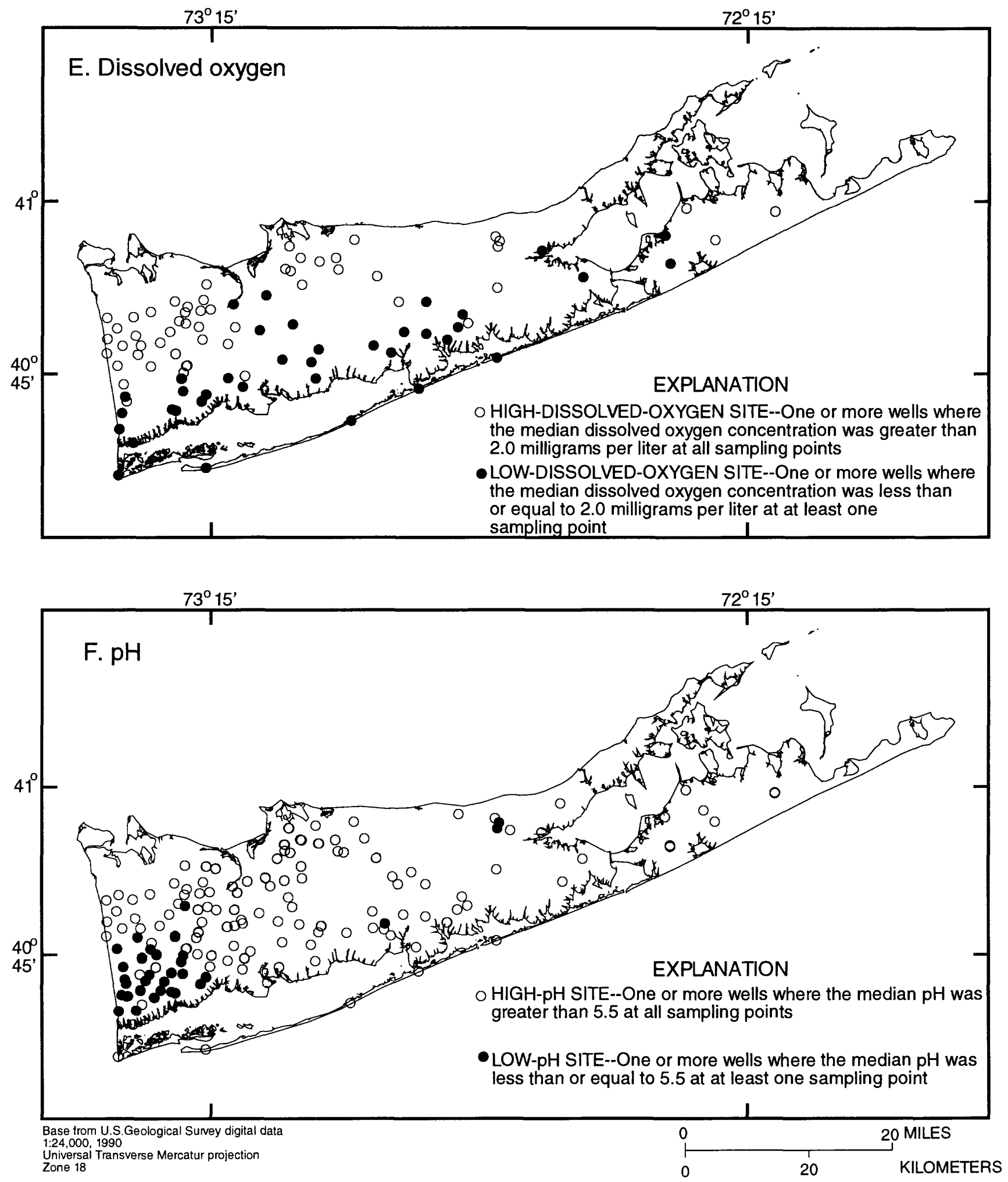

Figure 12 continued. Areal distribution of median values of selected constituents in wells screened in the Magothy aquifer, Suffolk County, N.Y. E. Dissolved-oxygen concentrations greater than 2.0 milligrams per liter. F. pH values less than 5.5. 

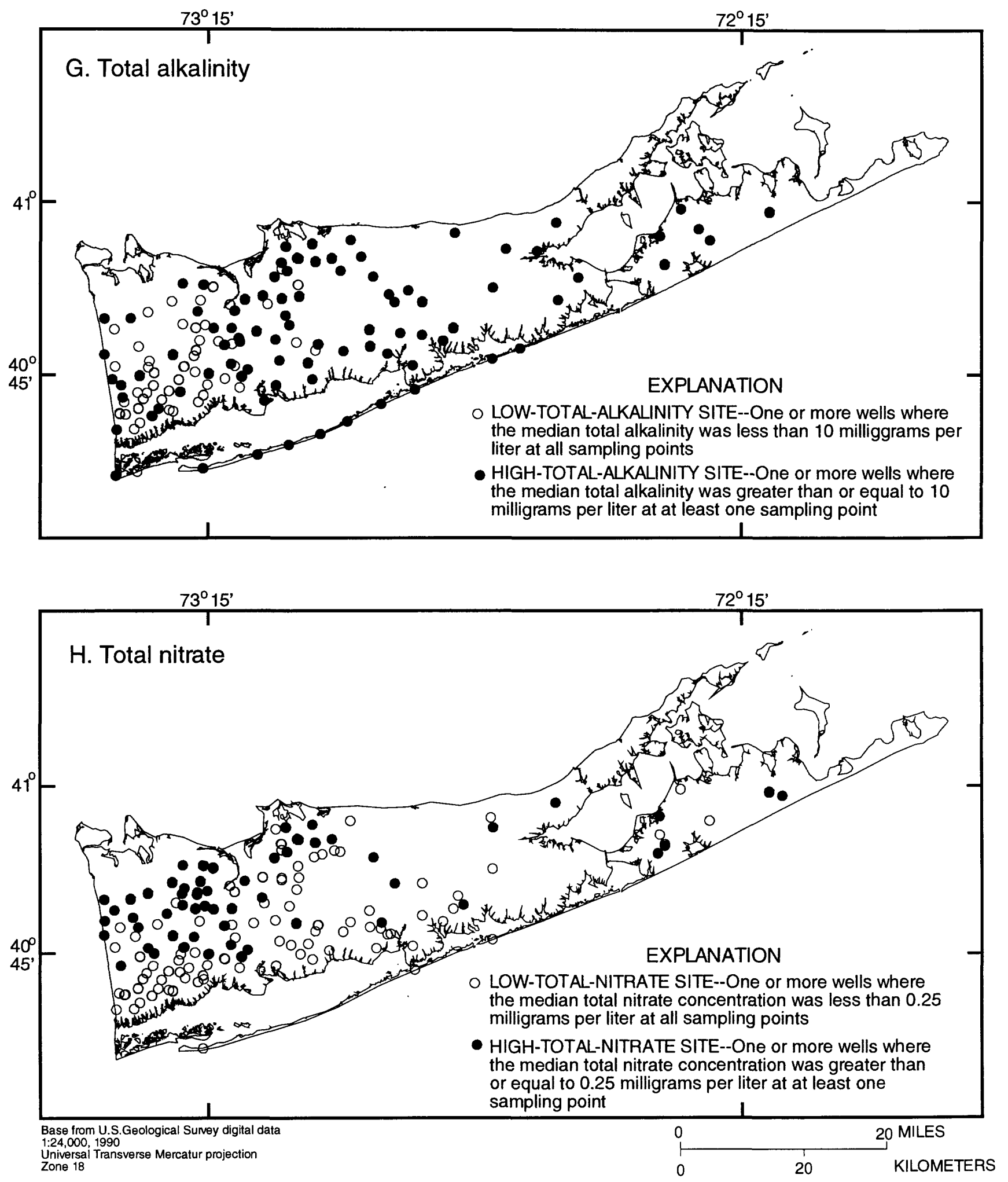

Figure 12 continued. Areal distribution of median values of selected constituents in wells screened in the Magothy aquifer, Suffolk County, N.Y. G. Total alkalinity less than 10 milligrams per liter as $\mathrm{CaCO}_{3}$. H. Nitrate concentration less than 0.25 milligrams per liter. 
explains the statistically higher concentration of total and dissolved iron in affected Magothy aquifer wells and also explains the tendency of iron-related specificcapacity decreases to occur in discharge zones, where total- and dissolved-iron concentrations are higher.

Statistical analysis of total- and dissolved-iron data indicate no statistical difference between unaffected and affected wells screened in the upper glacial aquifer. Biofouling in the upper glacial aquifer could occur while the wells are shut down because, during idle periods, water from the local distribution system is pumped into the well casing for lubrication, and water taken for this purpose from nearby wells that yield water high in iron thereby could introduce dissolved iron into an upper glacial well that yields water with a low iron concentration. This, in turn, could lead to biofouling of the well, even though iron concentrations are low while the well is in operation. This process could explain the lack of significant water-quality differences between unaffected and affected wells screened in the upper glacial aquifer.

\section{Manganese}

The spatial distribution of total manganese concentrations above $10 \mu \mathrm{g} / \mathrm{L}$ in the Magothy aquifer (fig. 12C) is similar to that of total iron. Wells with median total manganese concentrations greater than $10 \mu \mathrm{g} / \mathrm{L}$ are mostly along the southern shore and in central and east-central Suffolk County. No distribution map for dissolved manganese is presented because data were insufficient. Manganese chemistry in ground-water systems is similar to that of iron-the consumption of $\mathrm{O}_{2}$ and the subsequent reduction and dissolution of manganese oxyhydroxides along the flow path would introduce manganese into solution and, in turn, could cause elevated manganese concentrations in and near discharge zones.

Statistical analysis of total- and dissolved-manganese data indicate higher concentrations in affected wells than in unaffected wells in both aquifers. The chemical similarities between iron and manganese suggest that the biofouling process could also involve manganese. Iron bacteria that oxidize dissolved ferrous iron are also capable of oxidizing reduced manganese (Cullimore, 1986). The statistical differences between unaffected and affected wells suggests that manganese could participate in the biofouling process in both aquifers.

\section{Total Phosphorus}

The distribution of total phosphorus concentrations above $0.13 \mathrm{mg} / \mathrm{L}$ in the Magothy aquifer (fig. 12D) indicates that phosphate concentrations greater than $0.13 \mathrm{mg} / \mathrm{L}$ are mainly in the vicinity of discharge zones along the southern shore and in central Suffolk County. Phosphorus commonly is coprecipitated with iron and manganese oxyhydroxides. Adsorption onto, or coprecipitation, with iron and manganese oxyhydroxides is an important control on the solubility of phosphorus (Hem, 1985). The reduction and dissolution of iron and manganese oxyhydroxides in reducing environments such as those typically found in discharge zones would release phosphorus into solution.

Statistical analysis of total-phosphorus data from the Magothy aquifer indicate that the concentration of phosphate is significantly higher in affected wells than in unaffected wells. Phosphate is an important nutrient in ground-water systems and can be a limiting nutrient for the growth of iron-bacteria biofilms (Cullimore, 1986). The elevated concentrations of phosphate in affected wells suggests that phosphorus could be a limiting nutrient in the biofouling process in the Magothy aquifer. Also, the addition of phosphate as a chelating agent for iron directly into the casings of wells with high iron concentrations has led to rapid decreases in the specific capacities of those wells (Steven Colabufo, Suffolk County Water Authority, oral commun., 1989); this is further evidence that phosphate could be a limiting nutrient in the biofouling process. The lack of a statistically significant difference between concentrations of phosphate at unaffected wells and those at affected wells screened in the upper glacial aquifer suggests either that phosphate is not a limiting nutrient in the biofouling process in that aquifer, or that biofouling is occurring only while the wells are idle, as previously discussed.

\section{Dissolved Oxygen}

The distribution of dissolved oxygen concentrations below $2.0 \mathrm{mg} / \mathrm{L}$ in the Magothy aquifer (fig. 12E) is similar to the distribution of elevated concentrations of iron, manganese, and phosphate. Dissolved-oxygen concentrations less than $2.0 \mathrm{mg} / \mathrm{L}$ are mainly along the southern shore and in central Suffolk County; low concentrations in discharge zones indi- 
cates that conditions are more reducing than in recharge zones. The consumption of $\mathrm{O}_{2}$ by aerobic bacteria and by the oxidation of lignite lowers $\mathrm{O}_{2}$ concentrations in discharge zones.

Statistical analysis of dissolved-oxygen data indicate that dissolved-oxygen concentrations are significantly lower in affected wells than in unaffected wells. Oxygen is an important constituent in the biofouling process because the iron bacteria that form biofilms are aerobic. The growth of aerobic iron bacteria can begin at dissolved-oxygen concentrations between 0.02 and $0.2 \mathrm{mg} / \mathrm{L}$ (Cullimore, 1986). The most common and effective filamentous iron bacteria involved in the biofouling process in Suffolk County is the genus Gallionella, a microaerophile that prefers low-oxygen environments (Driscoll, 1987). The significantly lower concentrations of dissolved oxygen in affected wells than in unaffected wells could reflect the affinity of Gallionella for low-oxygen environments. There was no significant difference between dissolved-oxygen concentrations in unaffected wells and affected wells screened in the upper glacial aquifer. The median concentrations of dissolved oxygen at unaffected wells screened in both aquifers and affected wells screened in the upper glacial aquifer are above the upper limit of the optimum dissolved-oxygen range for Gallionella. The presence of affected wells in discharge zones, where reducing conditions predominate and iron concentrations are elevated, could indicate a correlation between large specific-capacity decreases and low concentrations of dissolved oxygen.

\section{pH}

The distribution of $\mathrm{pH}$ values above and below 5.5 in the Magothy aquifer (fig. 12F) indicates that $\mathrm{pH}$ values lower than 5.5 are mainly in the southwestern part of the county, where the largest withdrawals from the Magothy aquifer are made. The low $\mathrm{pH}$ values in this area could be the result of the drawdown of oxygenated water and the subsequent oxidation of authigenic pyrite, which is commonly found in the Magothy aquifer along the southern shore and would decrease the $\mathrm{pH}$ of ground water. Knobel and Phillips (1988) used the oxidation of pyrite to explain increases in the concentrations of iron and sulfate along flow paths in the Magothy aquifer in Maryland.

Statistical analysis of $\mathrm{pH}$ data indicate significantly lower $\mathrm{pH}$ values in affected wells screened in both aquifers than in unaffected wells. The kinetics of inorganic iron oxidation are second order with respect to $\mathrm{pH}$; the rate of iron oxidation would be faster at elevated $\mathrm{pH}$ values (Stumm and Morgan, 1981). In addition, most iron-oxidizing bacteria commonly found in supply wells prefer neutral $\mathrm{pH}$ environments ( $\mathrm{pH} 6$ to 7.6) (Cullimore, 1986); thus, water from affected wells in an acidic ground-water system could be expected to have higher $\mathrm{pH}$ values than water from unaffected wells. The lower $\mathrm{pH}$ of ambient ground water at affected wells is due to the location of most of the affected wells in southwestern Suffolk County, where $\mathrm{pH}$ values are low.

\section{Alkalinity}

The distribution of total field alkalinity (as $\left.\mathrm{CaCO}_{3}\right)$ above $10 \mathrm{mg} / \mathrm{L}$ in the Magothy aquifer (fig. 12G) indicates that water with total alkalinity less than $10 \mathrm{mg} / \mathrm{L}$ as $\mathrm{CaCO}_{3}$ is primarily in western Suffolk County. As water moves along a flow path, the oxidation of organic carbon such as lignite can increase concentrations of $\mathrm{HCO}_{3}{ }^{-}$and cause increased alkalinity. The microbially mediated oxidation of lignite, coupled with the reduction of iron and manganese, has been used to explain the origin of high concentrations of $\mathrm{HCO}_{3}{ }^{-}$in aquifers containing little or no carbonate minerals (Chapelle and Knobel, 1985; Pearson and Friedman, 1970). The natural presence of elevated alkalinity in discharge zones could explain the lack of wells in eastern Suffolk County, where flow paths are shallow and the degree of interaction with aquifer materials is less, at which alkalinities were less than $10 \mathrm{mg} / \mathrm{L}$ as $\mathrm{CaCO}_{3}$. The presence of alkalinities less than $10 \mathrm{mg} / \mathrm{L}$ in the southwestern part of Suffolk County could contribute to the low $\mathrm{pH}$ values observed there.

Statistical analysis of alkalinity data indicate that alkalinity is significantly lower in affected wells screened in the Magothy aquifer than in unaffected wells. Chemoautotrophic iron bacteria such as $\mathrm{Gal}$ lionella use inorganic carbon as a carbon source (Cullimore, 1986), which suggests that biofouling could be more common in wells with elevated alkalinity than in other wells. The significantly lower alkalinity in affected wells could be the result of a spatial bias. Almost all of the affected wells screened in the Magothy aquifer (fig. 2) are in western and central Suffolk County, where low alkalinity (less than $10 \mathrm{mg} / \mathrm{L}$ ) is common. 


\section{Nitrate}

Nitrate concentrations (as nitrogen) greater than $0.25 \mathrm{mg} / \mathrm{L}$ are found primarily in the inland recharge area in western Suffolk County (fig. 12H). Nitrate in ground water can undergo denitrification in lowoxygen environments; thus, the reducing environments associated with discharge zones contain lower concentrations of nitrate than the recharge areas.

Statistical analysis of nitrate data indicates that nitrate concentrations are significantly lower in affected wells in the Magothy aquifer than in unaffected wells. Nitrate is an important nutrient in many ground-water systems. High nitrate concentrations allow nitrate respiration by aerobic bacteria in lowoxygen environments, a process that can lead to significant biofouling (Cullimore, 1986). Thus, nitrate concentrations would be higher in affected wells than in unaffected wells if nitrate respiration is an important factor in the biofouling process. The lower concentrations of nitrate in the affected wells screened in the Magothy aquifer than in unaffected wells could be due to low nitrate concentrations along the southern shore, where most of the affected wells are located.

\section{Sulfate}

Median sulfate concentrations computed from the data base showed no significant spatial trends in the Magothy aquifer. Sulfate data collected from the Magothy aquifer throughout Suffolk County as part of an investigation into natural geochemical processes on Long Island indicate that dissolved sulfate concentrations greater than $3.0 \mathrm{mg} / \mathrm{L}$ are found primarily along the southern shore (Pearsall, 1996). The oxidation of authigenic pyrite has been used to explain increased sulfate concentrations along flow paths elsewhere in the Magothy aquifer (Knobel and Phillips, 1988). This process could explain the elevated concentrations of sulfate in discharge zones along the southern shore.

Statistical analysis of sulfate data indicate that dissolved sulfate was significantly higher at affected wells than at unaffected wells screened in both aquifers. Sulfate could be a nutrient in the biofouling process (Cullimore, 1986), and the reduction of sulfate by sulfate-reducing bacteria and the precipitation of iron sulfides also could be an important factor in the biofouling process. Iron-sulfide mineral phases are commonly found in iron biofilms and are attributed to the formation of microredox environments within the bio- films (George Alford, ARCC Inc., oral

commun., 1992).

\section{SUMMARY AND CONCLUSIONS}

The Suffolk County Water Authority (SCWA) is the largest water supplier on Long Island and in 1992 operated a network of 430 wells screened in the Magothy and upper glacial aquifers. Iron-related wellscreen encrustation and aquifer biofouling has affected many of the wells and has forced the SCWA to adopt a costly well-reconditioning and replacement program. The specific-capacity decreases are attributed to the growth of iron-bacteria biofilms composed of extracellular material and iron oxyhydroxides on well screens, in the gravel packs of wells, and in the surrounding formation in areas with elevated concentrations of iron in the ground water.

Specific-capacity decreases forced the SCWA to recondition 56 wells from October 1990 through August 1992. Initial specific capacities of SCWA wells screened in the upper glacial aquifer ranged from 5.4 to 229 ( $\mathrm{gal} / \mathrm{min}$ )/ft; the total decreases ranged from 0 to 85 percent. Initial specific capacities of SCWA wells screened in the Magothy aquifer ranged from 8.3 to 15 (gal/min)/ft; the total specific-capacity decreases ranged from 0 to 69 percent.

Magothy aquifer wells with annual specificcapacity decreases greater than 5 percent are mostly along the southern shore and in central Suffolk County, whereas upper glacial aquifer wells with annual specific-capacity decreases greater than 5 percent are mostly in south-central Suffolk County. These wells are primarily in ground-water discharge zones and are associated with elevated concentrations of iron.

Specific-capacity data and water-quality data for affected and unaffected wells screened in the Magothy aquifer indicate higher median concentrations of total and dissolved iron, total and dissolved manganese, total phosphate, and dissolved sulfate in samples from biofouled wells than in unaffected wells, and lower median concentrations of dissolved oxygen, total alkalinity, and pH. Data from the upper glacial aquifer indicate higher median concentrations of total and dissolved manganese and dissolved sulfate in biofouled wells than in unaffected wells and lower median $\mathrm{pH}$.

No spatial trends in the median values of constituents possibly related to the biofouling process were evident in the upper glacial aquifer, possibly because 
they were masked by the effects of human activities. Data from the Magothy aquifer show that concentrations of total and dissolved iron, total manganese, and total phosphate were higher along the southern shore and in central Suffolk County, in and near groundwater discharge zones, than elsewhere. Concentrations of dissolved oxygen less than $2.0 \mathrm{mg} / \mathrm{L}$ showed a similar distribution. Sulfate data from another investigation indicated that dissolved-sulfate concentrations were also higher along the southern shore than elsewhere. The spatial distribution of these concentrations is similar to that of wells with specific-capacity decreases greater than 5.0 percent per year in the Magothy aquifer, suggesting that ground-water quality affects the rate of biofouling. The biofouling of wells in areas with high concentrations of iron and manganese could be due to the presence of these metals as an energy source for the autotrophic iron bacteria that act as a biofouling agent. The elevated phosphate concentrations in biofouled wells suggest that phosphate could be a limiting nutrient in the biofouling process. The low dissolved-oxygen concentrations in biofouled wells screened in the Magothy aquifer could be due to the affinity of certain iron bacteria for low-oxygen environments. The high percentage of biofouled wells in discharge zones, where reducing conditions prevail, indicates a correlation between specific-capacity decreases greater than 5.0 percent per year and waterquality constituents associated with reducing environments, although no direct relation is defined.

Elevated nitrate concentrations are found mainly in northwestern Suffolk County. Biofouled wells commonly are in or near ground-water discharge zones in southern and southwestern Suffolk County, where nitrate reduction has occurred and nitrate concentrations are low. A zone of low $\mathrm{pH}$ was observed in southwestern Suffolk County, and a zone of low total alkalinity in western Suffolk County. Of the 64 wells used to create the biofouled-well data set, 44 are in water districts in southwestern Suffolk County, suggesting that the lower $\mathrm{pH}$ and total alkalinity values in affected wells may be due to a spatial bias.

\section{REFERENCES CITED}

Chapelle, F.H., and Knobel, L.L., 1985, Stable carbon isotopes of $\mathrm{HCO}_{3}$ in the Aquia Aquifer, Maryland: evidence for an isotopically heavy source of $\mathrm{CO}_{2}$ : Ground Water, v. 23, no. 5, p. 592-599.
Chapelle, F.H., and Lovley, D.R., 1992, Competitive exclusion of sulfate reduction by Fe(III)-reducing bacteria--a mechanism for producing discrete zones of high iron in ground-water: Ground Water, v. 30, no. 1, p. 29-36.

Cullimore, D.R., 1986, Physio-chemical factors in influencing the biofouling of groundwater: International symposium on biofouled aquifers--prevention and restoration: American Water Resources Association.

de Laguna, Wallace, 1964, Chemical quality of water at Brookhaven National Laboratory and vicinity, Suffolk County, New York: U.S. Geological Survey Bulletin 1156-D, p. 71.

Driscoll, F.G., 1986, Groundwater and wells (2nd ed.): St. Paul, Minn., Johnson Division, Universal Oil Products, $1,089 \mathrm{p}$.

Eckhardt, D.A.V., Siwiec, S.F., and Haefner, R.J., 1988, Ground-water quality in five land-use areas of Nassau and Suffolk Counties, Long Island, New York: EOS, Transactions, American Geophysical Union, v. 69, no. 6, p. 354.

Helsel, D.R., and Cohn, T.A., 1988, Estimation of descriptive statistics for multiply censored water quality data: Water Resources Research, v. 24, no. 12, p. 1997-2004.

Hem, J.D., 1989, Study and interpretation of the chemical characteristics of natural water: U.S. Geological Survey Water-Supply Paper 2254, 263 p.

Jensen, H.M., and Soren, Julian, 1974, Hydrogeologic data from selected wells and test holes in Suffolk County, Long Island, New York: Suffolk County Department of Environmental Control, Long Island Water Resources Bulletin LIWR-3, 35 p.

Knobel, L.L., and Phillips, S.W., 1988, Aqueous geochemistry of the Magothy aquifer, Maryland: U.S. Geological Survey Water-Supply Paper 2323, p. 28.

Lovley, D.R., and Phillips, E.J.P., 1988, Novel mode of microbial energy metabolism - organic carbon oxidation coupled to dissimilatory reduction of iron or manganese: Applied Environmental Microbiology, v. 54, no. 6, p. 1472-1480.

McClymonds, N.E., and Franke, O.L., 1972, Water-transmitting properties of aquifers on Long Island, N.Y.: U.S. Geological Survey Professional Paper 627-E, $24 \mathrm{p}$.

Pearsall, K.A., 1996, Comparison of ground-water quality in undisturbed areas with water quality in agricultural and residential areas of Long Island, New York,: U.S. Geological Survey Open-File Report 95-401, 11 p.

Pearson, F.J., and Friedman, Irving, 1970, Sources of dissolved carbonate in an aquifer free of carbonate mineral: Water Resources Research, v. 6, no. 6, p. 1775 1781. 
Reilly, T.E., Buxton, H.T., Franke, O.L., and Wait, R.L., 1983, Effects of sanitary sewers on ground-water levels and streams in Nassau and Suffolk Counties, New York-Part 1, geohydrology, modeling strategy, and regional evaluation: U.S. Geological Survey WaterResources Investigations Report 82-4045, 45 p.

Smolensky, D.A., Buxton, H.T., and Shernoff, P.K. 1989, Hydrogeologic framework of Long Island, New York: U.S. Geological Survey Hydrologic Investigations Atlas HA-709, 2 sheets, scale 1:250,000.
Stumm, W., and Morgan, J.J., 1981, Aquatic chemistry (2d ed.): New York, John Wiley, 780 p.

Walter, D.A., Geochemistry and microbiology of ironrelated well-screen encrustation and aquifer fiofouling in Suffolk County, Long Island, New York: U.S. Geological Survey Water-Resources Investigations Report 97-4032, in press.

Warren, M.A., de Laguna, Wallace, and Lusczynski, N.J., 1968, Hydrology of Brookhaven National Laboratory and vicinity, Suffolk County, New York: U.S. Geological Survey Bulletin 1156-C, 127 p. 